\title{
Depicting the Tree of Life: the Philosophical and Historical Roots of Evolutionary Tree Diagrams
}

\author{
Nathalie Gontier
}

Published online: 19 August 2011

(C) Springer Science+Business Media, LLC 2011

\begin{abstract}
It is a popularly held view that Darwin was the first author to draw a phylogenetic tree diagram. However, as is the case with most popular beliefs, this one also does not hold true. Firstly, Darwin never called his diagram of common descent a tree. Secondly, even before Darwin, tree diagrams were used by a variety of philosophical, religious, and secular scholars to depict phenomena such as "logical relationships," "affiliations," "genealogical descent," "affinity," and "historical relatedness" between the elements portrayed on the tree. Moreover, historically, tree diagrams themselves can be grouped into a larger class of diagrams that were drawn to depict natural and/or divine order in the world. In this paper, we trace the historical roots and cultural meanings of these tree diagrams. It will be demonstrated that tree diagrams as we know them are the outgrowth of ancient philosophical attempts to find the "true order" of the world, and to map the world "as it is" (ontologically), according to its true essence. This philosophical idea would begin a fascinating journey throughout Western European history. It lies at the foundation of the famous "scala naturae," as well as religious and secular genealogical thinking, especially in regard to divine, familial (kinship), and linguistic pedigrees that were often depicted by tree images. These scala naturae would fuse with genealogical, pedigree thinking, and the trees that
\end{abstract}

\section{N. Gontier $(\square)$}

Marie Curie Outgoing Research Fellow, Centre for Logic and Philosophy of Science, Vrije Universiteit Brussel,

Brussels, Belgium

e-mail: Nathalie.Gontier@vub.ac.be

URL: http://vub.academia.edu/NathalieGontier

\section{N. Gontier}

American Museum of Natural History, Division of Invertebrates, New York, NY, USA were the result of this blend would, from the nineteenth century onward, also include the element of time. The recognition of time would eventually lead to the recognition of evolution as a fact of nature, and subsequently, tree iconographies would come to represent exclusively the evolutionary descent of species.

Keywords Species classification · Evolutionary iconography · Tree of life · Networks · Diagram · Phylogeny · Genealogy Pedigree $\cdot$ Stammbaum $\cdot$ Affinity Natural selection

\section{Introduction}

In this paper, we focus on the "why" of tree iconography. Why did early biologists depict evolutionary descent in tree images? And of all things great and small, why were trees in particular deemed the most adequate?

To answer these questions, we must go back in history and consult some of the earliest written philosophical and religious texts of Indo-European culture. I'm going to take you to a time where tree diagrams illustrated just about everything but evolution.

We will begin our journey in Ancient Greece, where the great philosophers such as Plato and Aristotle, inspired by Egyptian and Asian religions, began to develop logical, dichotomous systems of classification with the goal of finding stability of knowledge in an ever-changing, continuous world of plenty.

We will examine how these ancient texts got synthesized with the Judeo-Christian religions, and how the logical classifications of the world were understood to represent a divine plan, a plan that could be illustrated by scales of nature, maps, and chains of being. 
Fig. 1 Example of a Porphyrian tree diagram

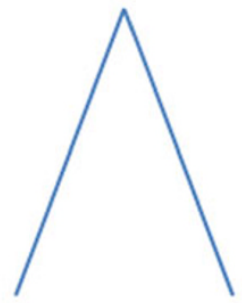

\section{animate inanimate}

Subsequently, it will be demonstrated how religious thinking laid the foundation of patriarchal genealogical thinking, i.e., the search for the natural (though nonevolutionary) affiliations of man. Genealogical thinking would directly feed into stemmatics and historical linguistics (Alter 1999; Morpurgo-Davies 1992), fields that occupied themselves with reconstructing the pedigrees of both manuscripts and languages.

By the nineteenth century, tree images would become rivaled by networks that depict the logical and natural affinities of species. Darwin would argue that the affinities between species are real and the result of a natural affiliation of all species. And this natural affiliation between species was explained to be the result of the transmutation of species over time through natural selection. It will, thus, be argued that Darwin evolutionized and synthesized both the thinking on affinities as well as pedigree thinking when he drew his hypothetical tree-like diagram that illustrated common evolutionary descent.

\section{Classifying the Order in the World with the Right Language}

Classification systems of the natural world are not necessarily based upon evolutionary thought. This is because most of the names given to the different ranks of life (e.g., Animalia, Plantae, Homo sapiens) stem from a time that precedes evolutionary biology. Without possessing modern genetics that enables one to abstract the core genes of a species, and the evolutionary common ancestry, how then, did these preevolutionary thinkers classify the world? By what means?
Fig. 2 Alonso de Proaza's illustration of Llull's description of a natural and logical, Porphyrian tree in his work De logica nova, published in the Valéncia edition (1512)

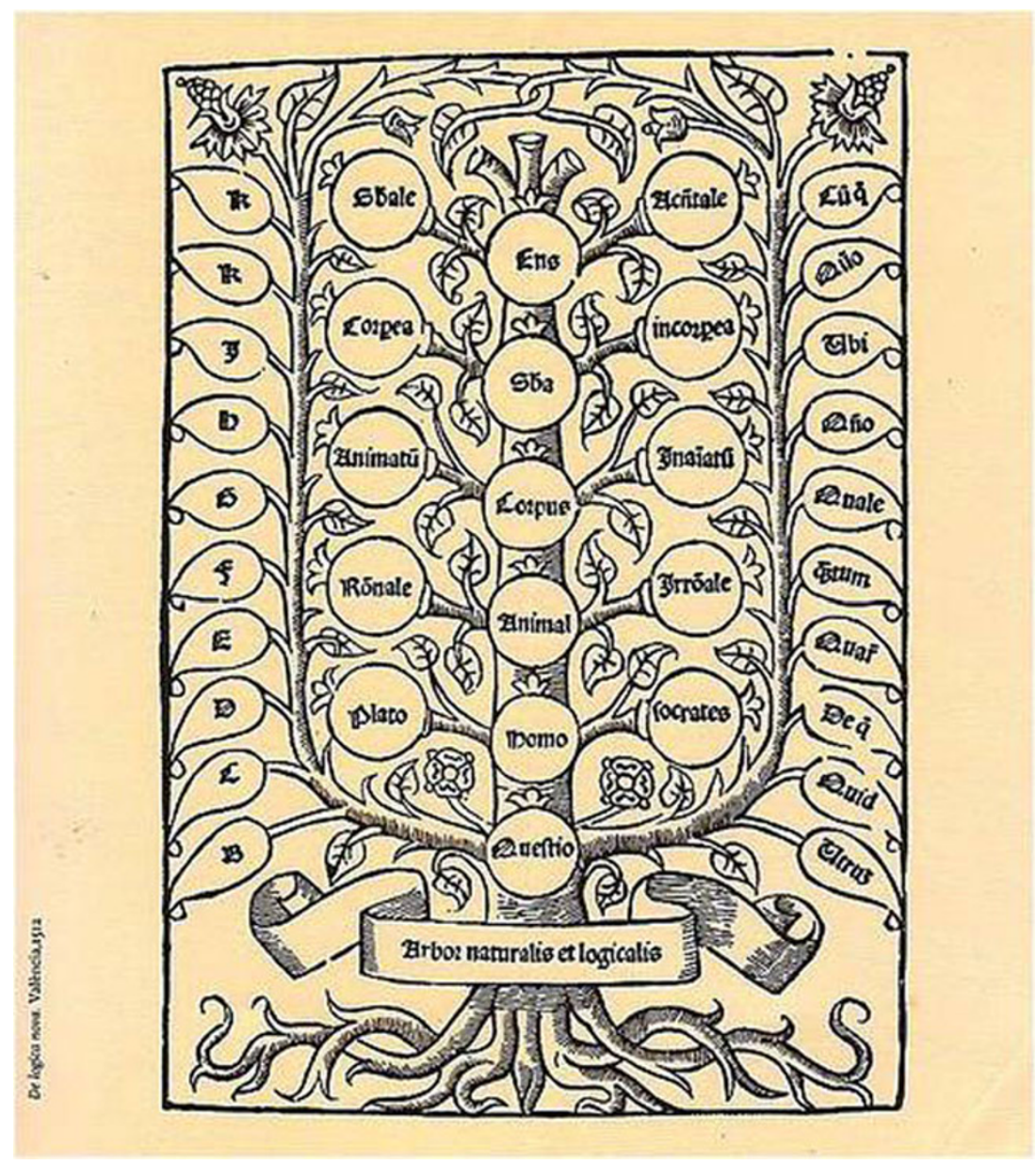


The most straightforward answer is: through language and observation. Through observation, scholars could examine life in its different forms, and through logic (reasoning by language), they could differentiate the organisms and their various traits, by giving them different names. And this is exactly what they did. As far as written human culture goes back, it has always been fascinated with how language enables us to refer to the world, to say both true and false things about it, and to classify its elements into different linguistic categories.

In other words, for the most part of western history, the most important instrument available to scholars was language. And because language was the only means by which knowledge could be obtained from the natural objects under investigation (most measurement techniques only evolved in the nineteenth century), language was either considered to be sacred or divine in and of itself, or to be the gift of a divine creator. In both cases, language was not, as now, understood to be a naturally evolved phenomenon that primarily enables communication. Language first and foremost enabled true and constant knowledge about the (divine) order in the world.

Whether one reads the Upanishads (Müller 1900), the Tao-teh-King (Hsüan and Crowley 1995), the teachings of Zoroastrism (Kapadia 1905), or the ancient Egyptian texts (Lichtheim 1976), all write that the world we live in is an orderly structured rather than a chaotic one. There appears to be a logic to the world that can be defined through language. As a consequence, for centuries scholars have been fascinated with finding the right language that enables us to call things by their right names.

In ancient Greek times (McKirahan 2003), the hierarchical order in the world would be called the logos (Coseriu
Fig. 3 Illustration drawn by Alonso de Proaza in 1512 to illuminate Llull's theory on the ascent and descent of the intellect, first formulated by Llull in 1302

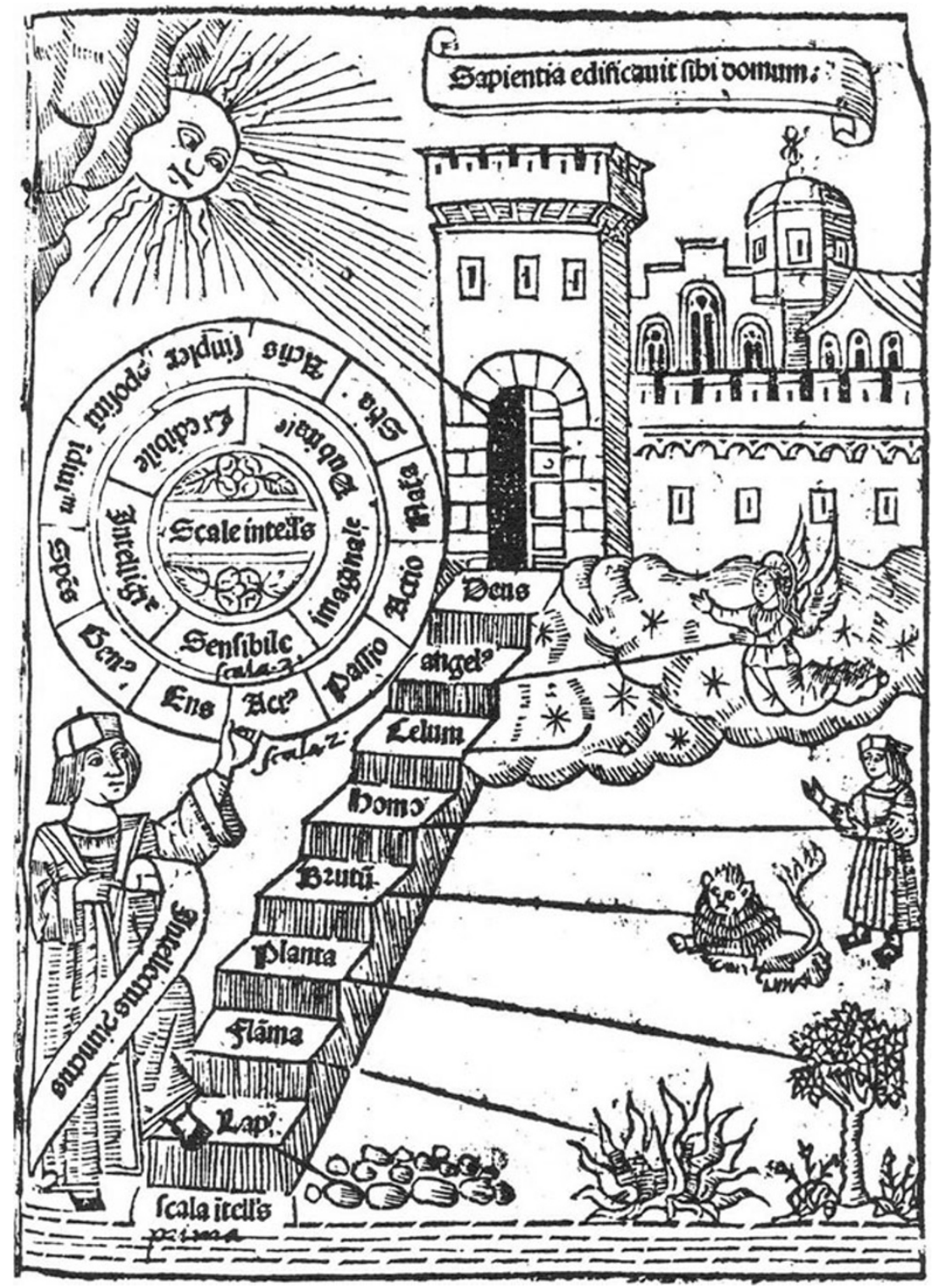


2003; Hillar 1998). That order and language were so intricately related to one another is clear by the following: the word logos does not only refer to the order in the world, it also translates as reasoning, logic, and language. Logos is furthermore the root word for knowledge and teaching and is remnant today in just about any science that ends with "logy," like the science of biology.

The ancient Greeks (McKirahan 2003) endorsed the idea that we live in a world of plenty, where everything that can possibly exist, does indeed exist (the principle of plenitude). Everything is also continuously moving (the principle of continuity); all is coming and becoming (Barsanti 1992). This coming and becoming needs to be understood not from within an evolutionary perspective but from within a cyclic worldview. Animals grow, thrive, and die; they are never constant but continuously move or are being moved. The principle that caused this constant coming and becoming was called the logos, and the logos itself was assumed to be constant or unmovable. Because the world and everything in it is continuously becoming, the underlying order of things often remains hidden, until it is spoken. Individual human beings, for example, go through a series of life cycles, and it is difficult to grasp what remains constant. Yet, we can group all individuals, and give them the name "human." Words therefore, according to Plato (Phaedus 245c-250d in Fowler 1921), allow us to grasp the essence of things: that which remains constant and is present in all individuals. Plato furthermore argued that these words or ideas (today we would call them concepts) are both constant and real; they are not prone to coming and becoming.

Elsewhere (Gontier 2008), I have already argued that the possession of language in a way enabled anybody who had it not only to find the order present in the world but also to create it. This creation of order implied classifying the world into linguistic categories that provide us with true and objective knowledge of the world. Naming is knowing, for the name of a thing was supposed to tell us something about its true essence. Perfect as the order in the world was understood to be, there could only be one language that called things by their proper names and that therefore gives us true knowledge of the world. All the other languages can merely provide false opinions (e.g., Plato's Cratylus in Fowler 1921).

As a result, the field of etymology would arise (Socrates' part in Plato's Cratylus in Fowler 1921) that seeks to find the original formulations of words (in the hope that the original words might also provide insight into the essence of the things they connote), and also, the field of logic would originate, which examines the way language refers to the world.

It might come as a surprise for the biology reader, but it is in this context of classification of substances that concepts such as genera and species first appeared (Wilkins 2009). Originally, these terms had nothing to do with natural history, let alone evolutionary theory. Instead, they were core concepts of metaphysics, a field in philosophy also known as ontology, or that branch of philosophy that deals with finding out what is true and real and what is merely a fiction of our imagination.

In his Republic, Plato (in Fowler 1921: 514a-520a) wrote a famous passage that today is known as the "Allegory of the Cave," wherein he argued that reality was layered into more and less real things. The thought of an image of a thing for example, is less real than the image of the thing or the thing in itself. In his philosophy, everything we see in this world is but a mere instantiation of real, true and perfect ideas that reside in a transcendental reality. To come to the essence of things, Plato, and especially Aristotle (in his Organon, Barnes 1984; Deverreux and Pellegrin 1990), would argue that we need to order the world by dividing the wholes into their parts and distinguishing the particular from the universal. Especially in the latter regard, genera and species came in handy. Living organisms could be grouped into species and genera, but so could anything else in the world be divided into genera (e.g., furniture), species (e.g., chair), and individuals (e.g., the chair you are now sitting on).

Controversy would arise over whether these genera and species actually exist (as realists would claim) or whether they are mere concepts that help in theory formation (as nominalists would argue). Plato, a realist, would argue that there exists a transcendental world that contains all ideas, i.e., all essences of things. Aristotle, on the contrary, would argue that essences are part of the things themselves.

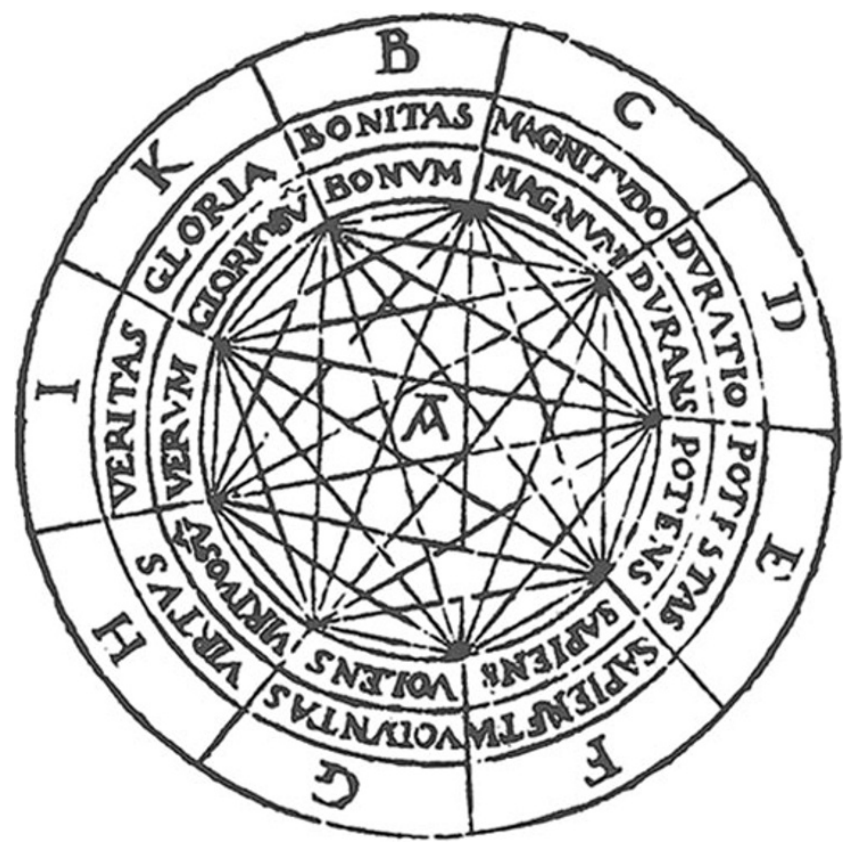

Fig. 4 The 16 attributes of God according to Llull. http://upload. wikimedia.org/wikipedia/commons/d/de/Ramon_Llull___Ars_Magna Tree_and_Fig_1.png 
That a chair is a piece of furniture is part of its essence, and this essence is somehow argued to be "carried" by the chair. Besides defining species based upon the genera they are part of, Aristotle (Deverreux and Pellegrin 1990) would also define species based upon their differentia. Differentia are qualities or properties possessed by one species in the genus but not by another. Humans for example, were animals that differed from all others through their reason and intellect. In other words, species got differentiated from one another based upon particular qualities they possessed or did not posses. Such dichotomous logical relationships would underlie all future classification systems.

As Lovejoy (1936) rightly points out, it is the Greeks' obsession with classification that would found ideas of a great chain of being or scala naturae (Barsanti 1995). The idea of a scala naturae first originated with Aristotle. In two of his works, The History of Animals and The Generation of Animals (Barnes 1984), he made the first attempt to classify

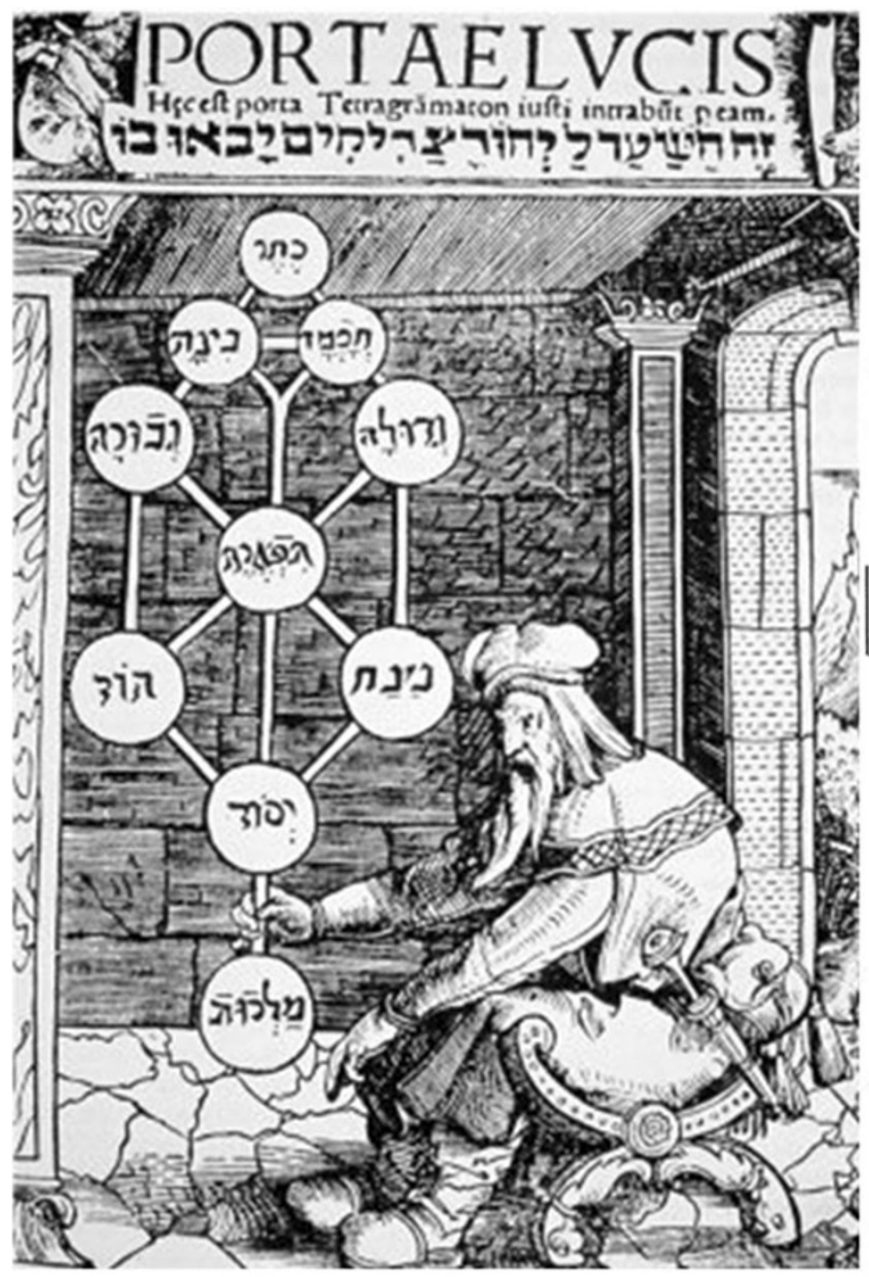

Fig. 5 Left, book cover of Paul Riccius' (1516) Portae Lucis that depicts the earliest representation of a cabalistic "tree of life." The ten Sephiroth are, from top to bottom and right to left, Crown, Wisdom, Understanding, Kindness, Severity, Beauty, Victory, Splendor, Founda- all beings in the world from inanimate (non-living and soulless) to animate (living and in possession of a soul).

Nature proceeds little by little from things lifeless to animal life in such a way that it is impossible to determine the exact line of demarcation, nor on which side thereof an intermediate form should lay. Thus, next after lifeless things comes the plant, and of plants one will differ from another as to its amount of apparent vitality; and, in a word, the whole genus of plants, whilst it is devoid of life as compared with an animal, is endowed with life as compared with other corporeal entities. Indeed, as we just remarked, there is observed in plants a continuous scale of ascent towards the animal. So, in the sea, there are certain objects concerning which one would be at a loss to determine whether they be animal or vegetable. For instance, certain of these objects are fairly rooted, and

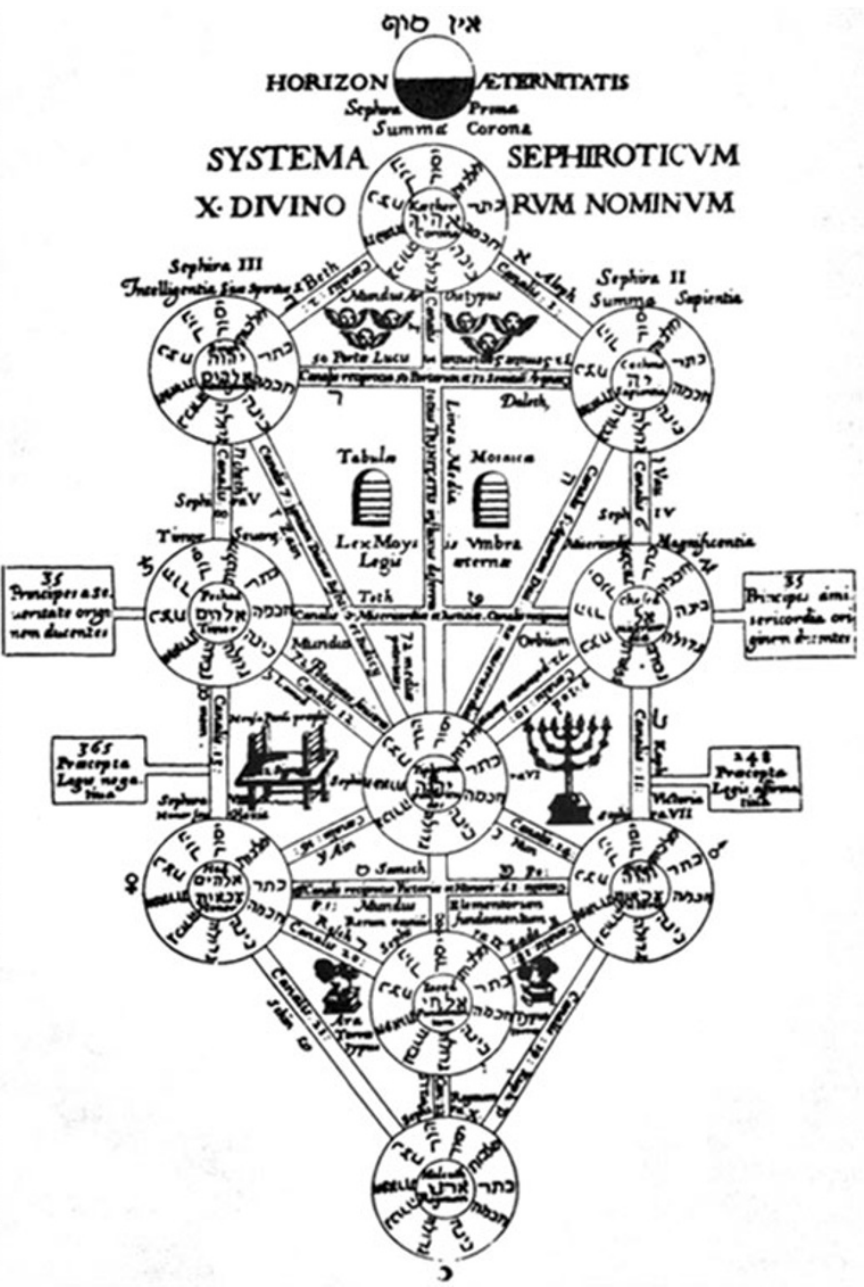

tion, and Kingdom. Right, the Tree of life as depicted by Kircher (1652). This tree of life not only illustrates the attributes of God, it also provides an advanced view of cosmology. http://upload.wikimedia.org/wikipedia/ commons/2/20/Kircher_Tree_of_Life.png 
Fig. 6 Top, Fludd's scale that intends to depict the whole of the universe (Fludd 1617-1621: 5 ). In the center of the spheres, the "ape of nature" (the human knowledge seeker) is represented holding a compass and globe in his hands (right, bottom). One of the ape's hands is chained by "mother" nature (the woman) whose hand in turn is chained by God (left, bottom) That man is depicted by an ape, is without any connection to present evolutionary theory. Under the globe upon which the ape sits, the spheres hierarchically represent, from core to outer spheres, the different human arts, the elements, plants, animals, the celestial bodies, and the angels. God stands outside and above creation. The rest of the image is filled with examples of the different spheres. Homo is depicted on the left

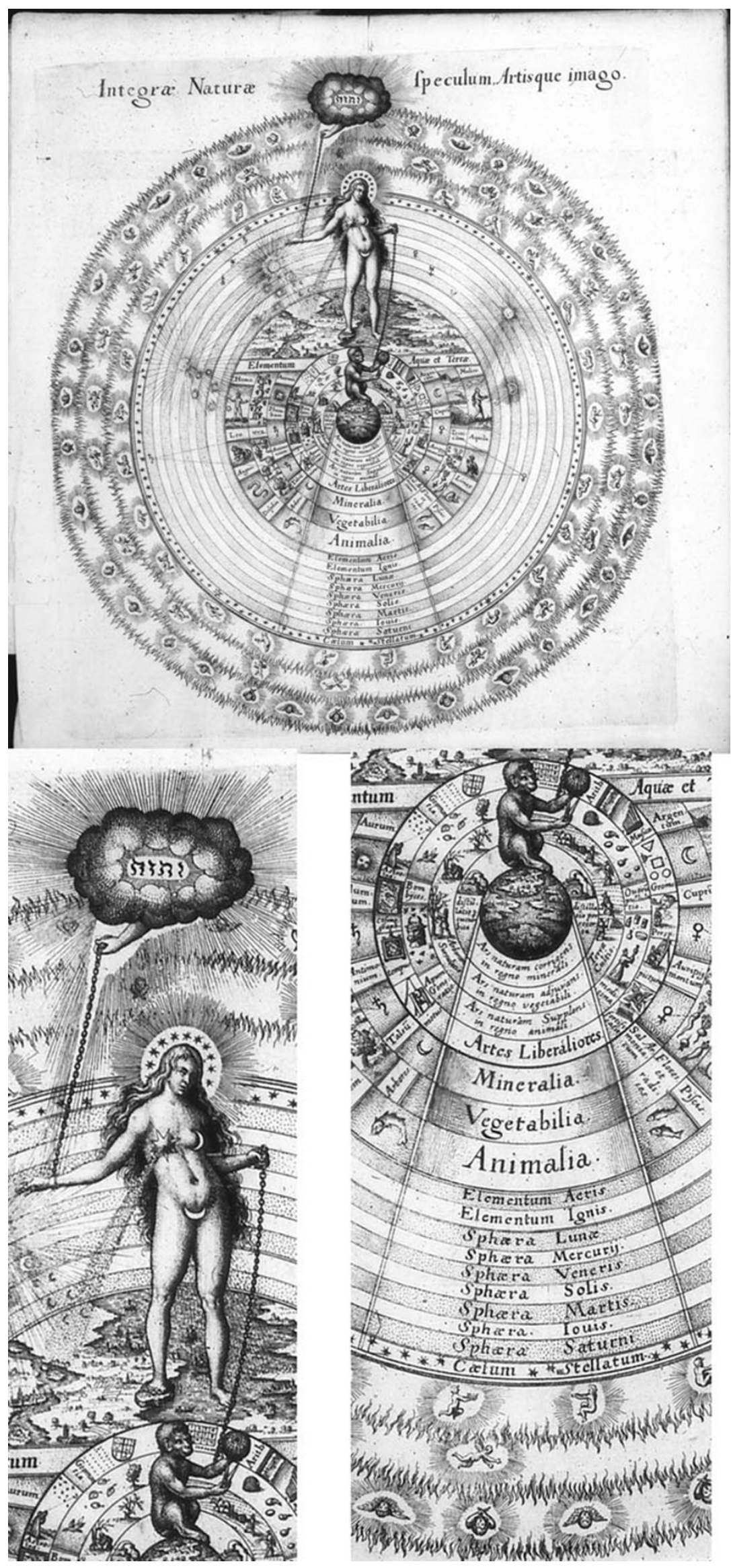


in several cases perish if detached. (Aristotle 588b:

4-14 in Barnes 1984; emphasis mine)

This "continuous scale of ascent" was based upon the kind of soul (Aristotle I, 1, 402-III, 13, 435 in Barnes 1984) the beings possessed (none for inanimate or lifeless beings, a vegetative, animal or intellectual soul for living beings); the potential they had to actualize; and the cause by which they actualized their potential (the moving principle or efficient cause, best compared with the mode of mobility the beings possessed). The scale was therefore also hierarchical, moving from the simple to the complex, the less perfect to the more perfect. The like was assumed to bring forth the like: in Aristotle's account, no evolution from one species to another or within species existed. Nonetheless, he argued that it was difficult to demarcate the elements on the scale, probably because in his view, everything was constantly coming and becoming. Biologists today still use some of the taxa first introduced by Aristotle.

The classification systems that could be built by making use of logic could be based upon true knowledge, or mere opinion, and so these systems themselves could also be classified hierarchically. The more accurate a system, or the language of the system, the more it truly represented reality, and the closer it literally became a reflection of reality. Finding the right logical system that enabled the true classification of the world would be the primary concern of Western philosophy up until the nineteenth century (Rieppel 2010).

One of the Neo-Platonists, Porphyry, would write both an introduction to, and a commentary on Aristotle's logical

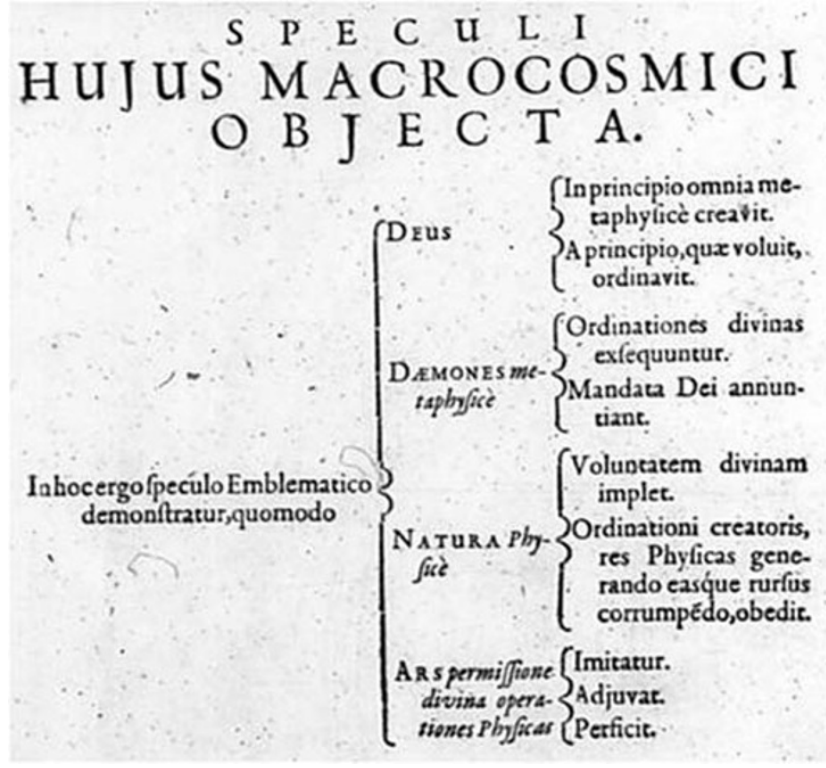

Fig. 7 A key of the structure of the macrocosmos from Fludd (1618: 6). The macrocosmos was hierarchically structured from God (the creator of everything) to demons (part of the metaphysical) to nature (the physical) to the arts (the study of the operation of the physical). The world's order was divine
Fig. 8 Charles Bonnet's famous ladder of natural beings that culminates with human beings, drawn in 1745 . http://upload. wikimedia.org/wikipedia/com mons/0/08/BonnetChain.jpg. In line with the philosophers and alchemists that preceded him, he includes the natural elements in his hierarchy and places them at the beginning of his scale. Although the scale does not include any supernatural beings, his scale of nature continues to have a religious undertone: the beings are hierarchically ordered in accordance to their assumed degree of perfection deduced from their type of soul. In accordance with Christian creation myths, the chain is understood to be fixed: there exists no historical or evolutionary relatedness between the elements of the chain. The ladder itself was also considered to be perfect; following Leibniz (Pombo 1987), this world was understood to be the best possible one

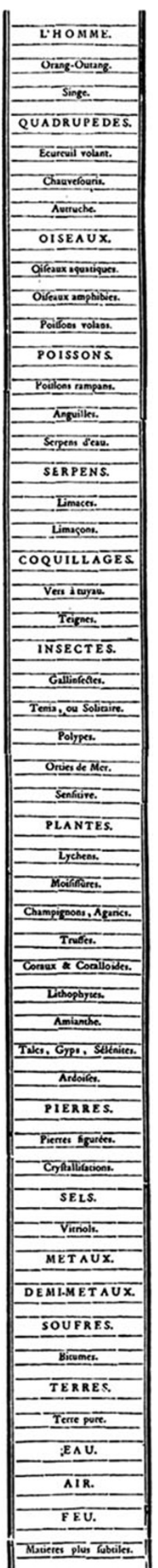


categories (Emilsson 2005). The commentary, entitled Isagoge, included an overview of different ancient writings on the hierarchical nature of genera and species (Pombo 2006: 221-3). Interpreters and translators of Porphyry's work would come to illustrate this hierarchy in diagrams of the following kind (Fig. 1): binary oppositions are the extreme ends of one, higher substance. The directionality of the legs of the diagram could be structured from top to bottom or vice versa, or from left to right, but in all cases, this diagram is always a timeless, evolutionless, and even unnatural structure. Ever since, brackets like these have been the major means to depict dichotomous logical relations between different elements.

Porphyry's Isagoge would become translated and commented upon by one of the most influential early Christian philosophers, Boethius, who in turn highly influenced the scholastics of the Middle Ages. Scholastics (de Libera 1995) are those philosophers that engaged in the "univer- salia debate": a continuation of the ancient Greek debate on how we can form logical systems to adequately categorize and refer to the world; and what the ontological status of language in these categorization systems is.

Tree metaphors are highly characteristic of Judaic and Christian religion. The book of Exodus talks about the appearance of God as a burning bush. Genesis tells the story of how Eve ate an apple from the tree of knowledge of good and evil, thereby causing her and Adam to be expelled from paradise. Knowledge for Christians was therefore iconographically associated with trees, and Porphyry's way of categorizing things easily allowed for a synthesis between his classification system and tree iconographies. These trees would become known as Arbor Porphyriana, Porphyrian trees, and they would become one of the most influential tools to depict logical relations amongst natural and supernatural things.
Fig. 9 The first Jesse tree as depicted in the Vyšehrad Codex of 1086, MS XIV.A.13, $420 \mathrm{~mm} \times 330 \mathrm{~mm}$, folio $4 \mathrm{v}$. Reprinted with permission from the National Library of the Czech Republic, Prague

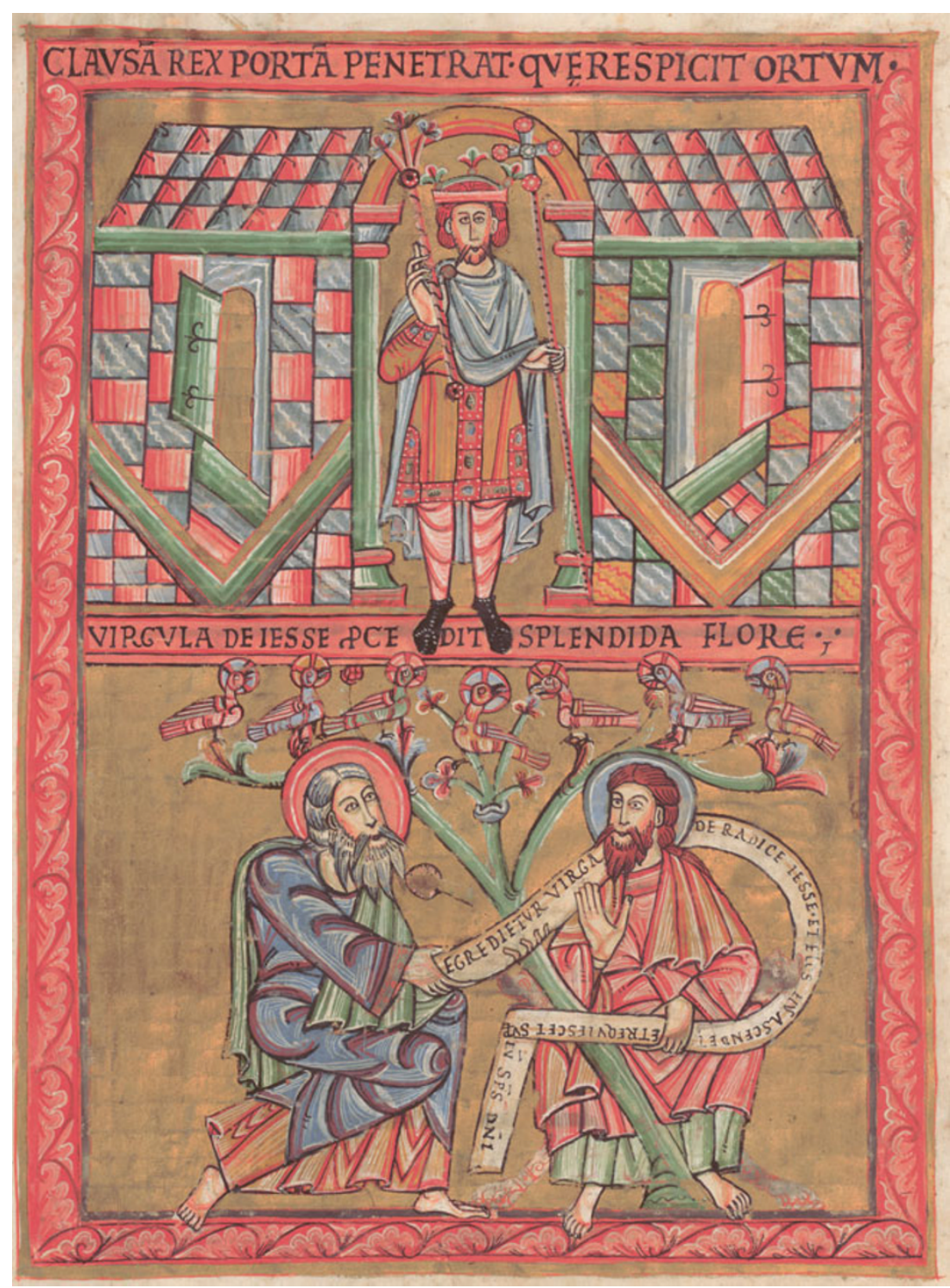


One of the scholars who made use of these trees was the Majorcan medieval philosopher Ramón Llull, who lived from 1232 to 1315 . He too engaged in the search for apt categories to gain knowledge of the world. And this knowledge, as a Christian scholar, took on the form of a tree. He even wrote a work in 1295 entitled Arbor Scientiae (Tree of Science). Figure 2 depicts the natural and logical Porphyrian tree as it was introduced in 1512 by Alonzo de Proaza to illustrate Lull's book On New Logic (De Logica Nova), written in 1303 (Llull 1303).

In another book of his that was entitled Liber de Ascensu et Descensu Intellectus (The book of the ascent and descent of the intellect), written in 1304, Llull combined Aristotle's ideas of a scale of nature with Christian theology (Llull 1304). The book described how the intellect could ascend and descend the chain of being from the elementary level up until the divine. Lull was a Christian scholar, but he spent most of his time in Muslim North Africa and would preach for the unification of Judaism, Christianity, and Islam. He was highly influenced by Plato, Plotinus and the Neo-Platonists (which in turn is more an Arab tradition), and Jewish cabbalism (Scholem 1995).

Inspired by Plato's Allegory of the Cave, Neo-Platonists such as Plotinus (de Libera 1995) would describe reality as a hierarchically layered structure that is closer or further away from "The One." The One was the name given to the single ordering principle that was assumed to lie at the creation of the plenty (i.e., the world and all its non-living and living elements). Christian scholars like Llull would associate The One with God. As in ancient Egypt, The One was compared to the Sun that shines its rays over the world. The further away from the sun, the less the rays shine upon it, and therefore the less perfect it is. The closer to the sun, the more it receives its heat, and by analogy, the closer a being is to the One or God, the more perfect that being is. The world could therefore be ordered in accordance to what was closer or further away from the Sun, or The One (ordering principle), or God.

At the base of Llull's chain of being lie natural elements such as stones and fire. These are followed by plants and animals, humans and angels. The latter stand closest to God, who stands at the top of the chain. Llull argued that the intellect can ascend and descend the "ladder" of divine creation through intellectual exercise, from the elements via the natural beings, over the angels, through God. Because the intellect was able to make such a journey on the stairway to heaven, it was also able to gain knowledge of these elements. In the Valéncia edition of this work, published several centuries later in 1512, Alonso de Proaza would also illustrate this idea of the ascent and descent of the intellect (Fig. 3).

The circles in the illustration of Llull's works are also important. Circles represented another "scale" by which knowledge could be depicted (Barsanti 1992; Pombo 2006). Trees and circles were the most common way to represent any type of knowledge system in the Middle Ages. Spheres were used because they were assumed to be perfect and more harmonious than trees. The circle in the illustration represents the different types of intellect. Llull made a series of such circle scales, including one that listed the 16 properties of God (Fig. 4).

Listing the properties of God was another activity that was the result of categorizing the knowledge one had about God and his act of creation, and this knowledge too would not infrequently be illustrated in tree diagrams. The tradition of listing God's attributes can also be found, and might even have originated, in Judaism, especially in cabalism, a European school of thought that reigned from the eleventh to the thirteenth century. In the twelfth century, the notion of a tree of life first appeared in association with theorizing on the attributes of God in the cabbalistic book called Bahir (the content of this book is assumed to go back to the first century; Kaplan 1989).

This concept of a tree of life served as a visualization of the ten sephiroth or attributes of God (JHWH). It is called the tree of life because the attributes of God are also assumed to lend an insight into creation: the sephiroth are "emanations" and "enumerations" of God (Kaplan 1989). As was the case with Llull's work, the first illustration of the tree of life only appears in the sixteenth century, where it served as the cover of a book by Paul Riccius (1516) on cabbalism called De Portae Lucis (Fig. 5, left). In the image, the attributes of God are depicted as circles, and these circles are connected by "branches" that together depict the "tree of life." The cabalistic tree of life also presents a scale of nature; it isn't a stairway or ladder, but it does provide a representation of cosmology, as can be seen in a later drawing of the tree by Kircher that also includes celestial bodies (Fig. 5, right).

Scala naturae are often translated in English as chains of being. The concept of "chain of being" implies that all beings, natural, and, because of the religious undertones, also often supernatural beings, are connected to each other as elements on a chain. Each element has its necessary and fixed place within the chain. The order is hierarchical: elements that are placed higher on the scale have superiority over elements that are placed lower on the scale. The elements that form the chain are thus classified from less to more real, perfect, good, etc. And in Christian theology, they are also less or more perfect creations of God.

The concept of "scala naturae" however implies more than just a "chain of being": they are more than just a visualization of the creation of natural and supernatural beings and their placement in an ontological system. The 


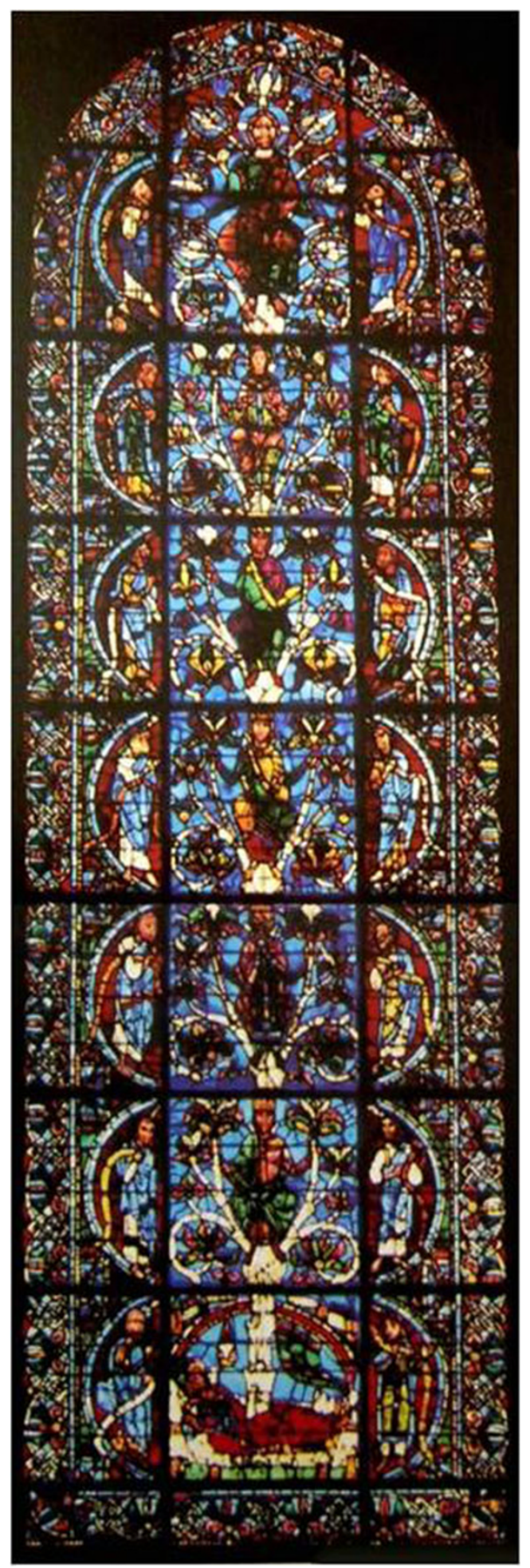

Fig. 10 The first stained glass that illustrates the tree of Jesse. The window, found in the French Cathedral of Chartres was constructed in 1145. http://upload.wikimedia.org/wikipedia/commons/8/85/France Chartres_JesseTree_c1145_a.JPG

scala naturae are meant to be true and actual scales, maps and measurements of the whole of nature. They are
Fig. 11 Upper left and right image, reconstruction of the IndoGermanic (Indo-European) language family by Schleicher (1853; 1861: 7). The left image dates from 1853, and the diagram was drawn in analogy to a plant. The image on the right dates from 1861 and resembles a tree diagram. The latter image especially needs to be interpreted from within both a historic and evolutionary view. Lower image, Čelakovskýs (1853: 3) tree diagram that represents the historic affinity of the Slavic languages

mappings of the true and whole structure of the world (Barsanti 1995).

The more advanced the knowledge of the natural world and the universe became, the more elements these scales of nature would include. The scala naturae are therefore best understood as part of a genuine enterprise to map all elements that exist in the universe, and also to demonstrate the place that all these elements have in creation. The sixteenth century alchemists (Silver 2000), chemists avant-la-lettre, would be responsible for the everincreasing number of elements and disciplines that needed to fit these scales in order to provide a true representation of both reality and the arts that study it. These scales would be depicted in trees and circles, or in a combination thereof.

In his book entitled Utriusque Cosmic Maioris Scilicet et Minris Metaphysica, Physica atque Technical Historia (Metaphysical, Physical and Technical Description of Both Worlds, Namely the Microcosmos and Macrocosmos) published from 1617 to 1621, Robert Fludd provides a more advanced scale (Fig. 6) that combined a representation of the universe with a representation of the human arts by which "the ape of nature" (the human being) can study the universe (Fludd 1617-1621), as well as a chain of being from the supernatural to the natural beings and elements (see also Griffioen 1996).

In the same book, he also provides a key (Fig. 7) of the macrocosmos. A strong case can be made for viewing such keys as more abstract representations of Porphyrian trees where brackets serve as "branches" of the "tree" and the binary oppositions are supplanted by a multitude of opposing elements in the system.

Scales and keys such as those found in the work of Fludd (1617-1621) would be drawn well into the nineteenth century, and together with ladders and chains they would be the major diagrams by which religious and more scientific works were illustrated (Barsanti 1995; Bowler 1973; Rieppel 2010). These diagrams would become filled with an ever-increasing number of elements and species, in parallel with an increasing knowledge of the natural world. But the principle idea underlying these scales would remain the same: everything in nature is assumed to be ordered by a divine plan (Fig. 8). 

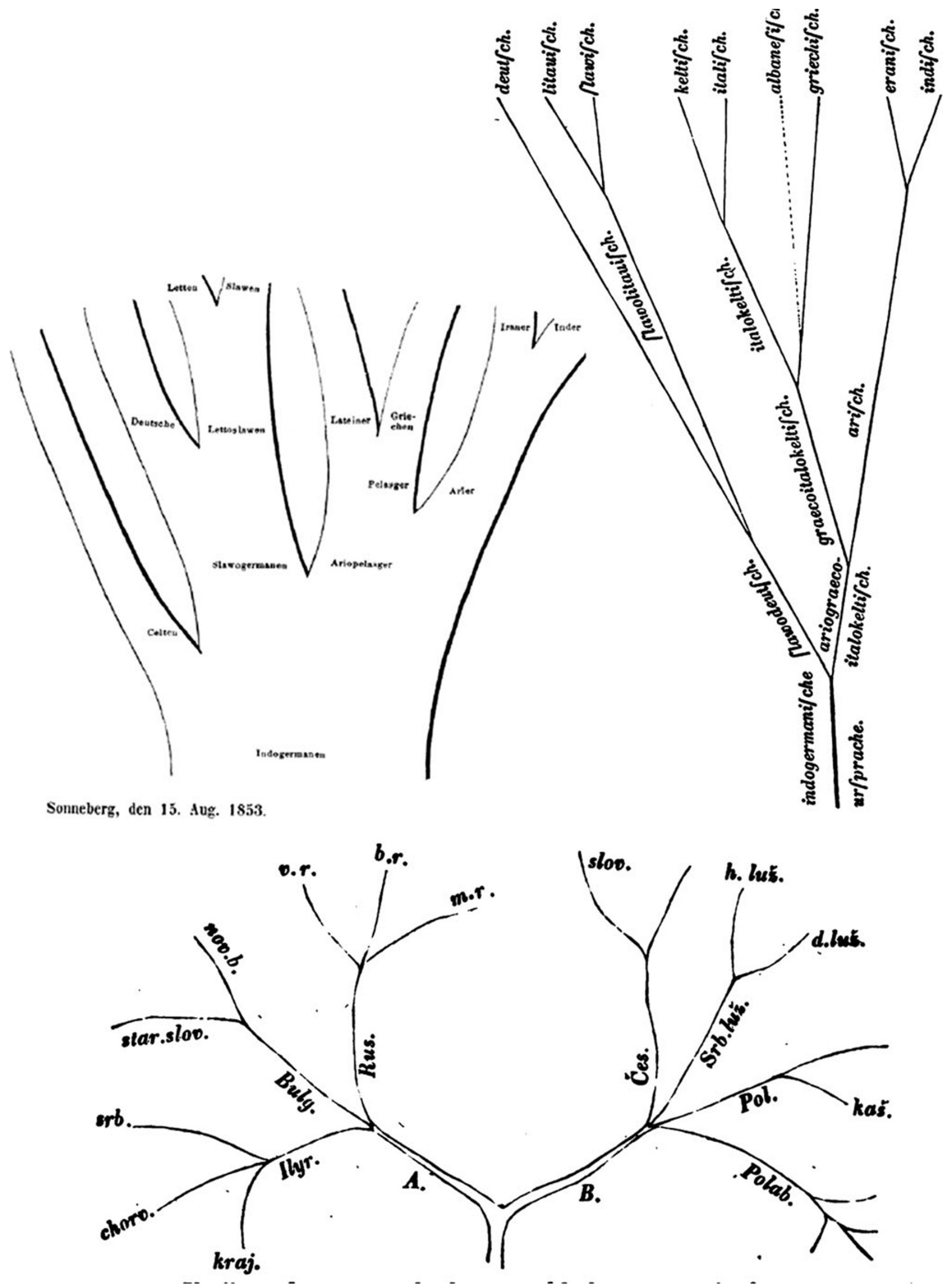


\section{Adam's Language and Genealogical Descent}

The three Abrahamic religions, Judaism, Christianity and Islam, are religions that claim to have knowledge of the spoken word of God and his prophets. In the Torah, God speaks directly to Adam and Eve, Noah or Job for example. In the New Testament, Jesus brings a message from God.

The revelations of these religions were thus of a linguistic nature. This was another reason why knowledge was understood to be language-like, and it is also one of the reasons that the field of etymology and logic were so important in the Middle Ages. In order to obtain true knowledge of the world and its creation, one needs to posses the right language to formulate this knowledge. But there are many languages spoken in the world, so finding the right language for knowledge was quite the endeavor (Gontier 2008). And besides natural languages, also mathematics and even music were sometimes understood to be instruments of knowledge (Condillac 1746; Coseriu 2003; Ecco 1995). Inspired by the Biblical story of the tower of Babel ("Genesis" 11: 5-7), it was assumed that all languages were descended from one original language, before the confusion of tongues occurred. This original language was speculated to be the language that was spoken by both Adam and God in paradise (Coseriu 2003; Gontier 2008). In "Genesis" (2: 19), Adam is said to have named the animals in God's image. The language according to which Adam named the things has long been understood to be the gift from God, and this Adamic language as it became called, was therefore argued to be a divine language. Consequently, it was thought that speaking this language would give divine powers: it would enable one to have true knowledge of the world and its creation, and to create oneself (Abracadabra, for example, literally means I create as I speak). Scholars would therefore start the search for this Adamic language.

One way to examine which language Adam spoke was by tracing Adam's descendants back to him. If one would be able to find direct descendents of Adam and discover to which nations these descendants belonged, one would be able to find out which language was the original one, spoken by this nation before the confusion of tongues. As such, the field of genealogy would be born.

The Bible (Anonymous 1997) itself already gives detailed descriptions of (often patrilinear) lines of descent of the most important figures in the Bible (Bouquet 1996); and there are passages where also the genealogy of Jesus (as the son of Mary and Joseph) is traced back to Adam (Luke, 3, 21-38; Isaiah 11, 1). Based on these pedigrees, "Trees of Jesse" would be drawn: non-evolutionary, patrilinear genealogical trees that trace the number of generations between Jesus and Adam. They are called "Trees of Jesse" because in these lines of descent one would find
David, the son of Jesse, who, via a series of ancestors, was the son of Adam who was argued to be the son of God. The earliest image of the tree of Jesse (Fig. 9) is depicted in the Czech Vyšehrad Codex and is dated to 1085-1086 (Williams 2000). The tree of Jesse became one of the most commonly produced Biblical images in medieval art and was also often found in glass windows of churches and cathedrals (Fig. 10).

The field of genealogy would flourish in both the Middle Ages and the Renaissance, and it is one of the major fields responsible for the use of tree iconographies to show kinship relations and common historical descent of divine and earthly families (Bouquet 1996). The less fancy and less artistic trees would resemble simple keys wherein brackets are used to connect parents to offspring. The depiction of females as circles, and males as squares, dates from these times, and is still a common practice of representation within current biology (Weigel 2003). Especially after the Reformation, European Protestant Bibles would have whole pedigrees drawn on the back of their front cover to facilitate Bible studies and to trace one's own roots (Bouquet 1996).

It was also these Protestant scholars who would discover meticulous methods to reconstruct the original single manuscript from a series of different Biblical writings that were written and rewritten by hand over many generations, thereby accumulating thousands and thousands of mistakes (Atkinson and Gray 2005; O'Hara 1996). Stemmatics, the name given to the field that performs such textual analyses, also brought to light that languages change over time: words are written differently today. Stemma furthermore translates as pedigree or "stamm." All with the goal of discovering Adam's language and the right and true word of God, these methodologies by which the genealogy of texts were reconstructed could also be applied to reconstructing the way in which languages were originally written. Eventually, these studies would give rise to the field of comparative and historical linguistics.

It is important to note that in Europe, the concept of a "tree of life" was part of both scientific and natural language, and was considered to be synonymous with the English and French words "geneaology/généalogie" and "pedigree," and the English words "family tree," the German word "Stammbaum," or the Dutch words "stamboom" or "levensboom" (which literally translates as tree of [your] life). This demonstrates how natural it had become for European scholars to associate genealogy with tree iconography. The word "affiliation" also refers to the fact that such genealogies were based upon patrilinear lines (filius is Latin for son), an element that gets lost when the English use the term kinship. In Dutch and German, words exist such as "stamvader" or "stamm fahr" (father of the trunk or stock) or "voorzaat" (literally "pre-seed" but referring to a person's ancestors). Neither of these words at this time held any evolutionary 
connotations, and the trees of life were drawn without any knowledge of the laws of inheritance. At most, the patrilinear lines of descent can be interpreted from within preformationist ideas (Schwartz 1999) that argued that sperm contains the full human being in miniature size that then grows in the mother's womb and at birth gets a soul from God.

\section{Coming to Terms with History}

When Christian (especially Protestant) Europe started to "discover" the rest of the world and its indigenous people, it had to come to terms with the shocking fact that there were nations, languages and texts much older than the Christian, Greek, and Egyptian ones. These languages, their people and their texts neither fit the current scales of nature nor the chains of being. Questions like the following were raised: Are all these people children of God? Does God have a preferential stock?

Most of the discovered nations did not possess written language, and as said, the Abrahamic religions are religions of "the word" and "the book": the Torah, The New Testament, or the Qur'an. Having been preoccupied for centuries with finding the right words to frame the right knowledge to understand creation and thus to be a "good person," it seemed an incredible enigma to find nations that didn't even have a written language. How could they ever find salvation without being able to read the word of God? Didn't God reach out to them? Did he willingly leave them in a "state of innocence," a state that was comparable to a "paradise lost" (the state in the garden of Eden, before Eve ate from the apple of the tree of knowledge)? Or were they degenerated; instead of having progressed, had they undergone decay after creation (e.g., Rousseau 1971)?

Not possessing written language or scriptures, some of the discovered nations were literally placed outside and before history, in a period that became designated as pre-history, a term still used today. This period that precedes history was understood as a "primordial state of innocence," an "underdeveloped," "pre-Biblical," "natural," "urstate" (Hobbes 1968; Rousseau 1971). Missionaries were sent around the globe to teach these nations to read and write, and to teach them about the word of God. The fields of measurement would originate, which measured the length, cranial content, weight, speech, and culture of these different "ethnicities," all in order to be able to place them on the scales of nature and to find their place in the chain of being. And this in turn would boost false racial and eugenic ideas. But it would also lead to the rise of different scientific methods that would eventually result in the division of the sciences in the nineteenth century (Gontier 2008; Silver 2000).

The discovery of these different nations, their cultures, languages, soil, etc. caused European scholars to discover the element of time. Before, scales of nature were conceived as being timeless. In creation, there was higher and lower, more and less perfect, but not earlier and older. Greeks such as Aristotle adhered to a cyclic view of time, and in the JudeoChristian religions, everything had been created in but 6 days.

It is this discovery of time that would eventually pave the way for the recognition of evolution as a fact of nature occurring in species, land, climate, languages, etc. As a consequence, there would be an emancipation of the study of natural history from the study of the history of the

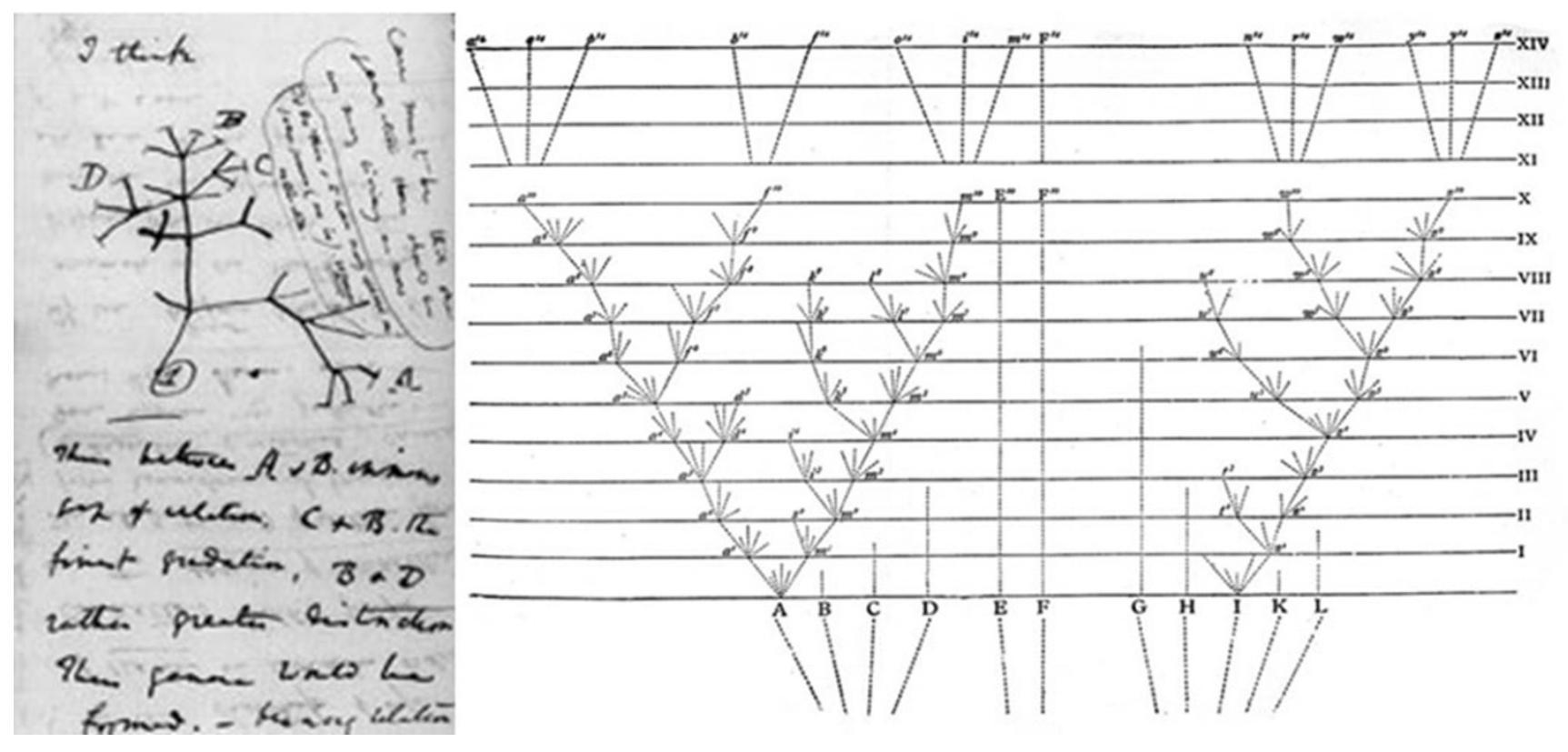

Fig. 12 Left, Darwin's first evolutionary diagram, drawn in his Notebook B in 1837 http://upload.wikimedia.org/wikipedia/en/8/83/Darwin tree_of_life.jpg. Right, Darwin's (1859: 116-7) hypothetical evolutionary diagram as it appeared in Origin 
supernatural (Barsanti 1995; Rieppel 2010). From the seventeenth century onwards, theism (the idea that God created the world and continuously intervenes) would trade places with deism (the idea that God created the world but does not intervene after creation).

Such as shift from Theism to Deism (Silver 2000) is especially visible in the eighteenth and nineteenth century rising fields of geology and paleontology. Scholars had to make sense of the increasing number of fossil finds demonstrating that species had undergone morphological change through time, or had even gone extinct. The scale turned out to be far less harmonious and continuous than was once assumed, and nature, more than a deity, was held responsible for the imperfections. Originally, the Earth's layers were understood as the result of several floods and other divinely imposed catastrophes, while scholars such as Hutton and Lyell would argue that the same natural laws that underlie the earth's formation today, also underlaid the earth's formation in the past (Schwartz 1999).

The study of natural history would therefore receive greater independence, and the role of God in creation would be constrained to an original creation act; thereafter, mechanical, natural laws would "take over."

The search for these laws that cause nature to change over time would define the new field of William Whewell's palaetiology, a science that included the fields of systematics (encompassing paleontology and biogeography), historical linguistics and stemmatics (the field that studies textual transmission; O'Hara 1996: 7-9). All these fields would illustrate their findings with tree diagrams that, in

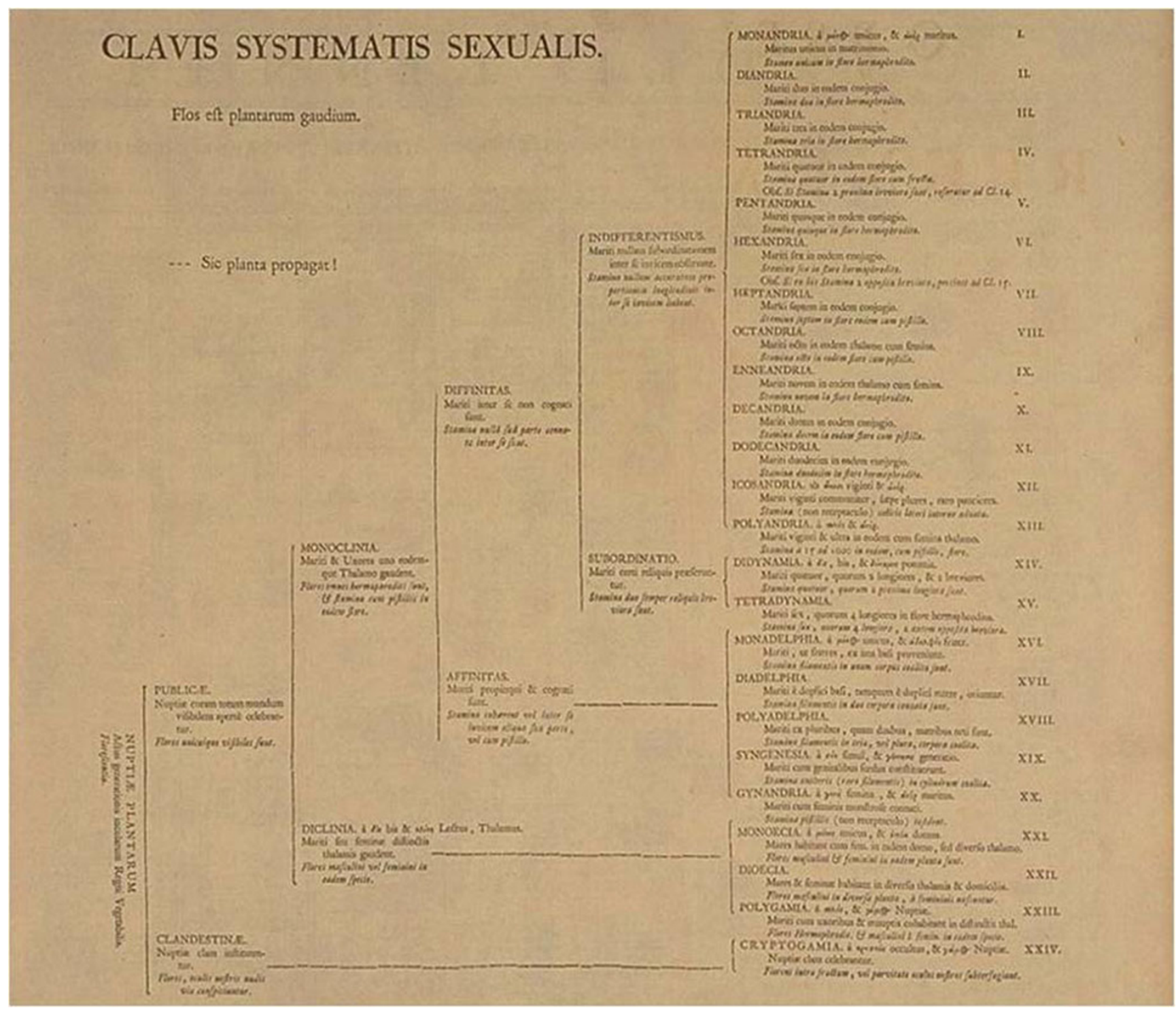

Fig. 13 Linnaeus' (1735) key of the sexual system of plants. http://upload.wikimedia.org/wikipedia/commons/5/53/Linn\%C3\%A9-Clavis Systematis_Sexualis_1735.jpg 
contrast with older drawings, would include the element of time. Moreover, as we shall see, these tree diagrams too would literally be called "pedigrees," "Stammbaume," "family trees," or "genealogies."

Historical linguistics (Alter 1999; Atkinson and Gray 2005; Van Wyhe 2005) was one of the first fields that would move away from the study of the divine order in the world to study the natural order and its history through time. Inspired by moral and political philosophers such as Hobbes (1968) and Rousseau (1971), these scholars would argue that Adam and his descendents had invented their own language instead of having received language from God (Gontier 2008). All languages were therefore natural, and some languages were even older than the European ones. As a result, the study of the history of these natural languages became a major topic of investigation.

One of the most important scholars to introduce the study of the natural history and kinship-wise connectedness of the different human languages was Auguste Schleicher (1853; 1861; 1863), a German linguist and close friend of Ernst Haeckel (Richards 2002). The term "natural history" should be taken quite literally here. Schleicher (1861: 1-2) would argue that languages are best understood as natural, living organisms (Frank 2008; Frank and Gontier 2010). Like all natural beings, languages also come into being, thrive for a while, and eventually die. Linguistics was a "science of life" and therefore part of the natural history of man. The linguistic method, according to Schleicher (1861: 1), was essentially the same as that of the natural sciences. More specifically:

One of the main goals of the science of language is the determination and description of linguistic kinships and speech trunks. This encompasses finding the one urlanguage from which all languages descend and ordering the linguistic kinships according to a natural system. (Schleicher 1861: 1, my translation ${ }^{1}$ )

Thus, according to Schleicher, languages were related to one another, and their affiliation could be traced back to urlanguages. Schleicher furthermore assumed that there were multiple "stammbaume," "pedigrees" of languages, and thus he adhered to a multiple origin of language (1861: 2). He elaborated as follows:

The life of language (usually called the history of language) is distinguishable into two main branches:

1. development of language, prehistoric period. With humans, language, i.e. the verbal expression of thought, developed. Even the simplest language is

\footnotetext{
1 "Eine der Hauptaufgaben der glottik ist die Ermittlung und Beschreibung der sprachlichen Sippen oder Sprachstämme, d.h. der von einer und der selben Ursprache ab stammenden sprachen und die Anordnung dieser Sippen nach einem natürlichen Systeme." (Schleicher 1861: 1)
}

the result of a gradual becoming. All higher speech forms are brought forth from simpler ones, synthetic languages are brought forth by isolating languages, flexional (fusional) languages are brought forth by synthetic ones. 2. Decay of language in utterance and form, whereby also significant changes in function and sentence construction occur, historical period. The transition from the first to the second period occurs gradually. The main task of linguistics is to determine the laws according to which languages change during their course of life. Without such knowledge, one cannot possibly understand the nature of the studied languages, especially those languages that are still alive. (Schleicher 1861: 4, my translation) ${ }^{2}$

Languages developed gradually with the development of humans in a primordial, prehistoric state. This prehistoric period gradually transitioned to a historical one, where languages underwent change and decay and eventually went extinct. Although he still uses the term "development" (entwickelung) instead of evolution, Schleicher's theories are to be understood in a wholly natural and even evolutionary way. ${ }^{3}$ Nonetheless, his theory is still biased toward the cultural ideas of his time. The "prehistoric" period was romanticized as being more paradise-like and perfect, since in historic times, languages underwent decay.

Schleicher would become known for reconstructing the "stammbaum" of the Indo-European language family (Fig. 11, left and right). His linguistic family tree provided insight into the natural kinship history of these "natural beings."

It is a commonly endorsed thought that Schleicher only came to his ideas on language after reading Darwin's Origin of Species, which was published in 1859. The Origin includes a famous passage where Darwin argues that a

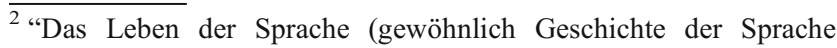
genannt) zerfällt in zwei hauptabschnitte: 1. Entwickelung der Sprache, vorhistorische Periode. Mit dem Menschen entwickelte sich die Sprache d.h. der lautliche Ausdruck des Denkens. Auch die einfachste Sprache ist das Ergebnis eines allmählichen Werdens. Alle höheren sprachformen sind aus einfacheren hervor gegangen, die zusammen fügende sprachform aus der isolierenden, die flektierende aus der zusammen fügenden. 2. verfall der Sprache in laut und Form, wobei zugleich in Funktion und Satzbau bedeutende Veränderungen stattfinden, historische Periode. Der Übergang von der ersten zur zweiten Periode ist ein allmählicher. Die Gesetze zu ermitteln, nach welchen sich die sprachen im verlaufe irres Lebens verändern, ist eine der Hauptaufgaben der glottik, den ohne Kenntnis der selben ist kein Verständnis der Formen der vor liegenden sprachen, Besondern der jetzt noch lebenden, möglich." (Schleicher 1861: 4).

${ }^{3}$ Darwin (1859) only used the term evolution once, on the last page of Origin. Instead, he wrote about the "transmutation" of species. One of the reasons for this might be that the term evolution originally was used by preformationists to describe the mere unfolding or development of preformed eggs or sperms in the womb (Schwartz 1999).
} 
pedigree of man would also provide insight into the pedigree of man's languages, a genealogy that would provide the "filiations" of all tongues.

If we possessed a perfect pedigree of mankind, a genealogical arrangement of the races of man would afford the best classification of the various languages now spoken throughout the world; and if all extinct languages, and all intermediate and slowly changing dialects, had to be included, such an arrangement would, I think, be the only possible one. Yet it might be that some very ancient language had altered little, and had given rise to few new languages, whilst others (owing to the spreading and subsequent isolation and states of civilization of the several races, descended from a common race) had altered much, and had given rise to many new languages and dialects. The various degrees of difference in the languages from the same stock, would have to be expressed by groups subordinate to groups; but the proper or even only possible arrangement would still be genealogical; and this would be strictly natural, as it would connect together all languages, extinct and modern, by the closest affinities, and would give the filiation and origin of each tongue. (Darwin 1859: 422-423; emphasis mine)

In the next section, we will see how Darwin intended this piece of text to illustrate his new way of classification, based upon common descent. Here, we remain focused on the Darwin-Haeckel-Schleicher connection. According to Atkinson and Gray (2005: 517) and Maher (1983), Haeckel recommended Schleicher to read Darwin's Origin only in 1863. Schleicher read Darwin's work and replied to it in the same year (1863) with a work entitled Die Darwinische Theorie und die Sprachwissenschaft (Darwins Theory and the Science of Language). In it, he argued that historical linguistics could provide the theory of evolution by means of natural selection with actual historical examples of the process, because Darwin's diagram (Fig. 11) was only a hypothetical one (Hull 2002; Richards 2002). Nonetheless, Schleicher also emphasized that he came to his theory of language change and diversification independently from Darwin's theory, a statement that can be proven by the fact that he already drew tree diagrams of the Indo-European language family in 1853 (Fig. 11, left), before Origin was written, and 1861 (Fig. 11, right), before Schleicher read Darwin's Origin. Schleicher (1853) found the inspiration for his first diagram in botany, but further research needs to be done in regard to which authors inspired him. It is certain that, especially in botany, there had been a history of research on affinities between different plant species (Ragan 2009).

According to O'Hara (1996: 84) and Priestley (1975), Schleicher might have also been influenced by Čelakovský, a Czech linguist who was working on the genealogy of the Slavic languages. He summarized his findings in a linguistic pedigree (Fig. 11, beneath) which he presumably drew in 1852. The tree diagram was published a year later, after Čelakovský's death. And being a linguist, it is indeed highly likely that Schleicher was also aware of the work being done by philologists on stemma (Atkinson and O'Hara 2005: 517).

In a famous passage of The Descent of Man, Darwin would again write of the striking similarity between the evolution of language and species.

The formation of different languages and of distinct species, and the proofs that both have been developed through a gradual process, are curiously the same... We find in distinct languages striking homologies due to community of descent, and analogies due to a similar process of formation...Languages, like organic beings, can be classed in groups under groups; and they can be classed either naturally according to descent, or artificially by other characters. Dominant languages and dialects spread widely and lead to the gradual extinction of other tongues. A language, like a species, when once extinct, never, as Sir C. Lyell remarks, reappears. The same language never has two birth-places. Distinct languages may be crossed or blended together. We see variability in every tongue, and new words are continually cropping up; but as there is a limit to the powers of the memory, single words, like whole languages, gradually become extinct. As Max Müller has well remarked:-'A struggle for life is constantly going on amongst the words and grammatical forms in each language. The better, the shorter, the easier forms are constantly gaining the upper hand, and they owe their success to their own inherent virtue.' To these more important causes of the survival of certain words, mere novelty may, I think, be added; for there is in the mind of man a strong love for slight changes in all things. The survival or preservation of certain favored words in the struggle for existence is natural selection. (Darwin 1871: 59-61)

Schleicher, however, had already written on the parallels between Darwinism and the evolution of languages in 1863. By the nineteenth century, tree iconographies and brackets upon brackets were thus not at all an uncommon way to depict genealogical or logical relations, either between supernatural or natural beings, languages or knowledge systems. Even Diderot's Encyclopedia shows such tree diagrams and keys to illustrate the process of knowledge formation (Weigel 2003). By then, and without any knowledge of the laws of reproduction, it had also become common knowledge that humans, languages, 


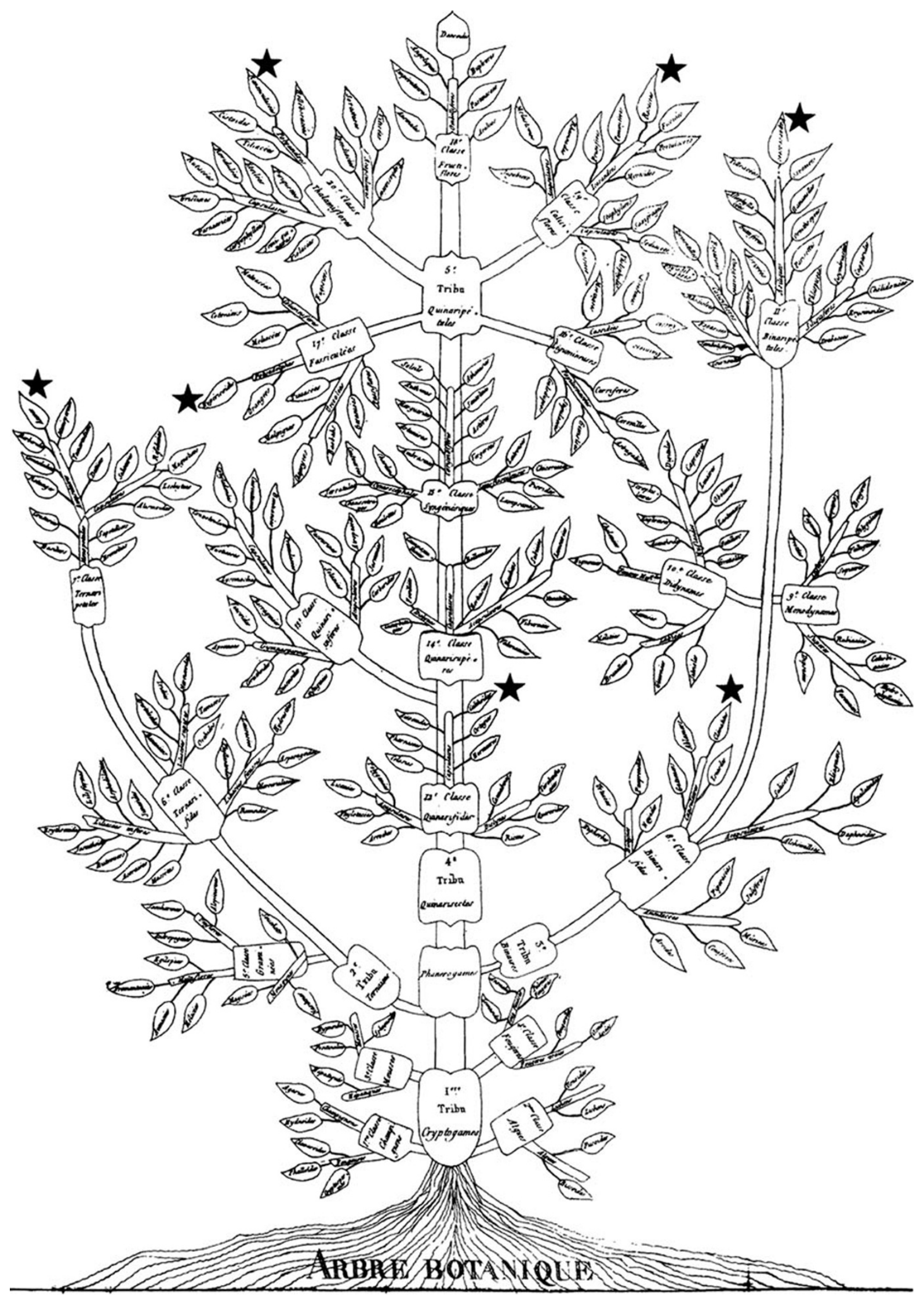

Fig. 14 Augier's botanical tree, first published in 1801 
nations, and the whole of the physical world shared some sort of affinity (Ragan 2009): a historical relationship, based upon natural kinship and thus common descent. It wouldn't take long now before the reason for this historical affinity would be sought.

\section{The Study of Natural History: from Affinity to Evolution}

As groundbreaking as the idea of evolution by means of natural selection might have been, Darwin did not formulate this theory in a scientific vacuum. On the contrary, his ideas were formulated and visualized with a language and imagery that had been developing for centuries. When Darwin published his hypothetical phylogenetic diagram (Fig. 12), it was not the image itself that was new, but the interpretation. For the first time, it was assumed that species share a common history of descent with modification because they transmutate due to natural selection. In a passage written right before he speculates on the similarities between the pedigree of man and the different human languages (discussed in the previous passage), he says just that:

All the foregoing rules and aids and difficulties in classification are explained, if I do not greatly deceive myself, on the view that the natural system is founded on descent with modification; that the characters which naturalists consider as showing true affinity between any two or more species, are those which have been inherited from a common parent, and, in so far, all true classification is genealogical; that community of descent is the hidden bond which naturalists have been unconsciously seeking, and not

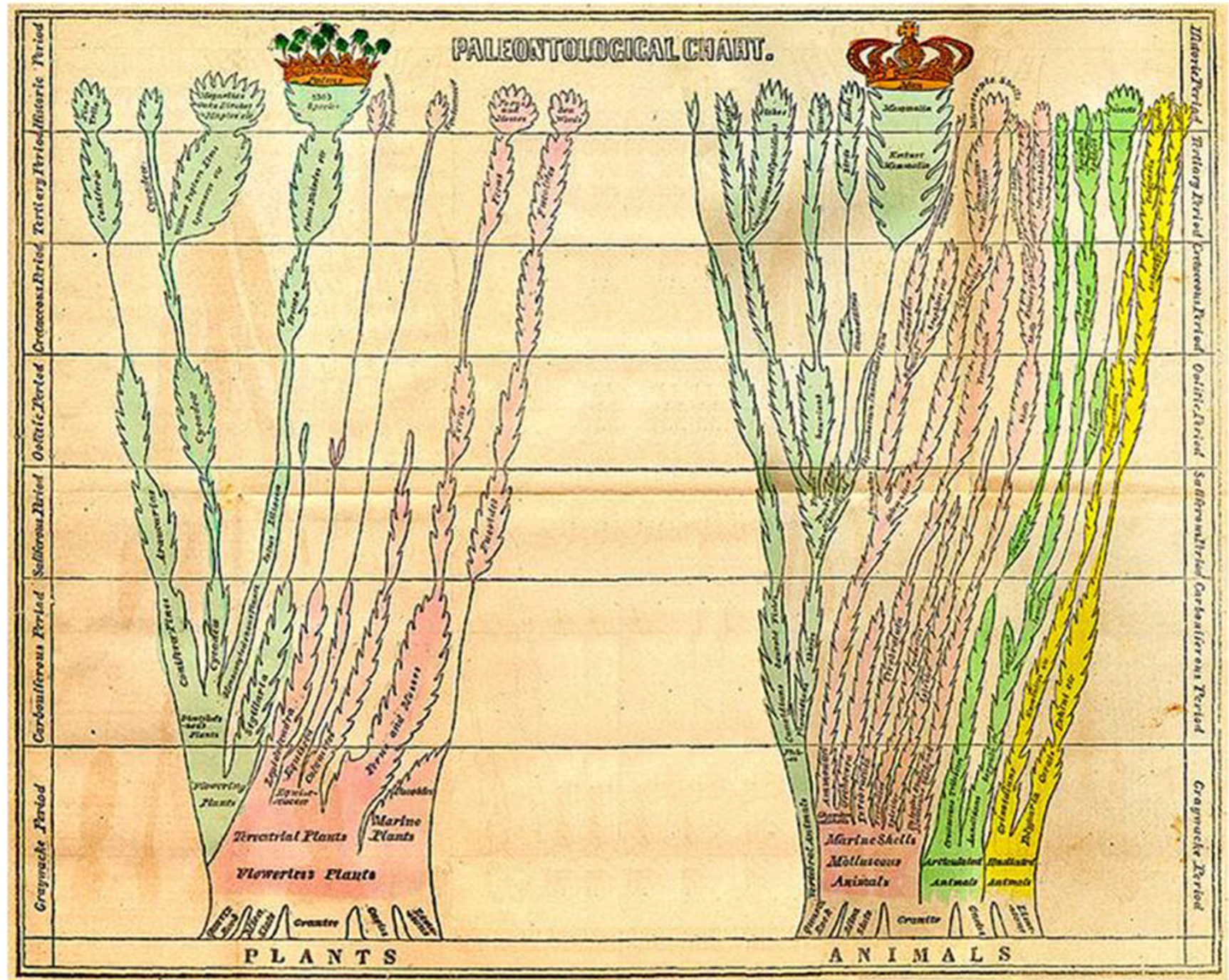

Fig. 15 Hitchcock's non-evolutionary paleontological chart drawn in 1840. http://upload.wikimedia.org/wikipedia/commons/8/8f/Edward Hitchcock_Paleontological_Chart.jpg 
some unknown plan of creation, or the enunciation of general propositions, and the mere putting together and separating objects more or less alike. (Darwin 1859: 420; emphasis mine)

Darwin's ambition was nothing less than an attempt to reconstruct the natural, reproductive bloodline of all of life in a pedigree because organic beings were "related to each other in the same degree in blood" (Darwin 1859: 421). Therefore, all true classification is genealogical, and genealogy becomes based upon the inheritance of traits through the blood line. He preferred to draw a branching diagram (that he himself never called a tree) that would show these affiliations over an artificial logical key, in order to emphasize how related his ideas were with pedigree thinking.

This natural arrangement is shown, as far as is possible on paper, in the diagram, but in much too simple a manner. If a branching diagram had not been used, and only the names of the groups had been written in a linear series, it would have been still less possible to have given a natural arrangement; and it is notoriously not possible to represent in a series, on a flat surface, the affinities which we discover in nature amongst the beings of the same group. Thus, on the view which I hold, the natural system is genealogical in its arrangement, like a pedigree; but the degrees of modification which the different groups have undergone, have to be expressed by ranking them under different so-called genera, sub-families, families, sections, orders, and classes. (Darwin 1859: 422; emphasis mine)

According to Darwin, the logical keys that classify species and genera based upon differentia, and the networks that group natural affinities, cannot adequately represent the way in which shared traits are passed on from one generation through the next, with modification.

Before Darwin's time, from the mid-eighteenth century onward, natural classification systems would no longer be depicted by scales or ladder-like iconographies. Scholars had come to acknowledge that life on earth somehow appeared to share common characteristics, "affinities": "regularities of resemblance or arrangement among characteristic or functionally important body parts...that indicated an attraction or closeness between the organisms or taxa in which they were found" (Ragan 2009). These affinities could form the basis of classification instead of the theorizing on essences and the assumed degree of perfection an organism portrayed. Affinities were often depicted in diagrams that held the middle between Porphyrian trees and keys. Barsanti (1992) and Ragan (2009) demonstrate how networks were also drawn to show the myriad of traits different species often share with one another. The natural history students that drew such diagrams were often deists, and in accordance with their convictions, they literally placed God out of the natural picture. A shift took place: from trying to map the world as it had been created, to mapping the different forms of life by the number of traits that are held in common. The notion of affinity is therefore strongly correlated to the notion of homology (Ragan 2009).

Although still religiously committed, Linnaeus' (1735) well-known classifications of the natural world are instances of such diagrams. He introduced new terminology and moved away from essentialist thinking. He classified the organisms based upon the affinity they possess in their natural traits. Nonetheless, genera and species remain classified based upon distinguishable, binary oppositions, in line with the tradition set out in Porphyian trees. A good example of this is Linnaeus' classification of the sexual system of plants (Fig. 13). He called it the marriage of plants and classified

\section{. T A B L E A U. \\ Servant à montrer l'origine des différens animaux.}

Vers.

Infusoires, -

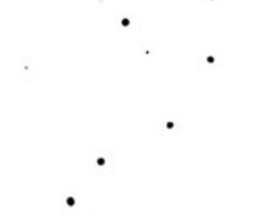

Annelides. Cirrhipèdes. Mollusques.

Polypes. Radiaires.

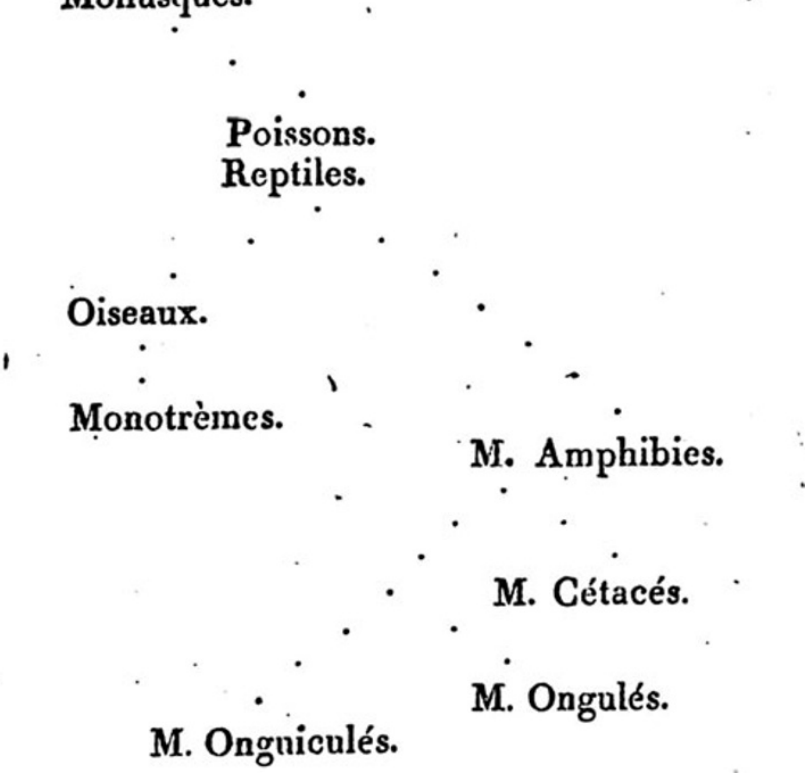

Fig. 16 Lamarck's diagram of the origin of animals, published in his Philosophié Zoologique in 1809: 643 
the system according to binary oppositions such as public and clandestine marriages; and amongst the public marriages, there were those where husband and wife have the same bed or separate beds and so on.

In 1801, Augustin Augier (1801; Stevens 1983; Bersanti 1995 ) would revise the classification of plants, and he would classify them into a tree diagram (Fig. 14) that nonetheless was understood to represent a scale of nature. No evolutionary undertone can be attributed to his tree, but time was represented. Time formed a major element in Hitchcock's paleontological chart (Fig. 15), drawn in 1840, but he did not think in terms of evolution and even strongly opposed such views when they became formulated (Archibald 2009).

A diagram that would for the first time include the element of time along with natural affinity, is the diagram drawn by Lamarck in 1809 to illustrate the origin of animals (Fig. 16). Lamarck (1809) first and foremost tried to come to terms with the change species underwent through time. Through use and disuse of certain traits and the inheritance of acquired characteristics, organisms could start to deviate from the common stock and increase in their adaptedness and thus increase in their perfection. He still endorsed a Biblical view of creation, but he argued that there could be "evolution" within a species, away from the

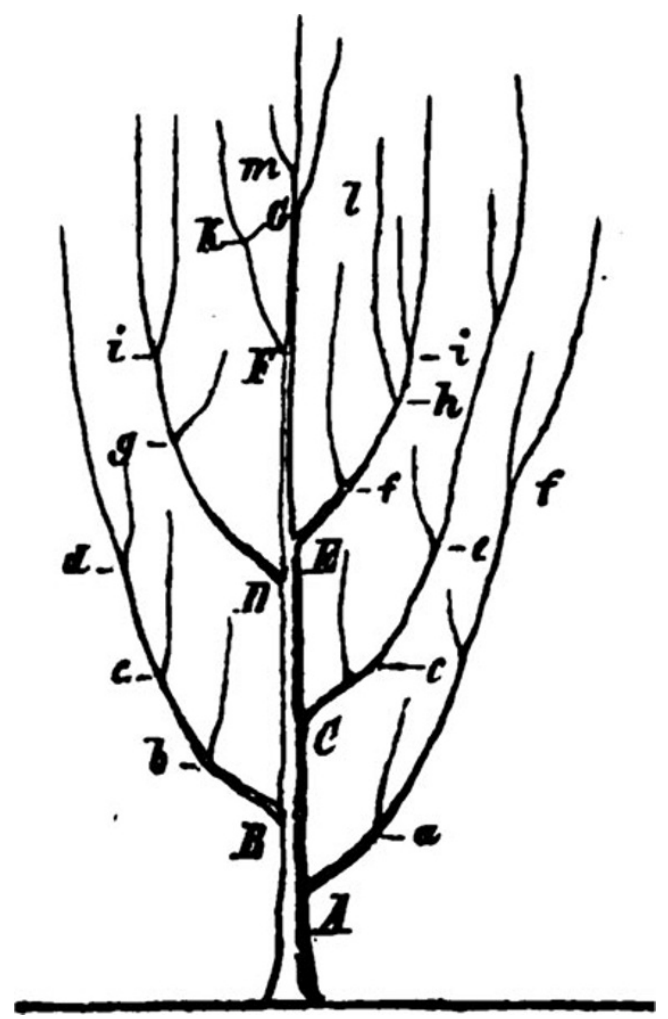

Fig. 17 Bronn's tree diagram that illustrates his theories on how more-developed species develop later in time than less-developed species (Bronn 1858: 481)
Fig. 18 First monophyletic tree of organisms, drawn by Haeckel in 1866. http://upload.wikimedia.org/wikipedia/commons/thumb/b/bc/ Haeckel_arbol_bn.png/220px-Haeckel_arbol_bn.png

prototype. In his account, disuse could not lead to extinction.

In 1857, Heinrich Bronn received a prize from the French Academy of Sciences for his work on the developmental history of the organic world in the light of the timely formation of the earth's surface. In 1858, Bronn published the work in German, and in it, he drew a tree diagram (Fig. 17) to illustrate the successive finds of ever more complex appearing species in the fossil record. He argued that species did not appear all at once in the fossil record, but that they appeared sequentially in time, one after the other. Moreover, later appearing animals were more complex and perfect (vollkommner) than earlier appearing animals. The development of animals (entwickelung) was therefore understood to be progressive (Bronn 1858: 481-2).

It is common knowledge that Darwin was inspired by authors such as Lamarck and Linnaeus, and Burrow (1972) argues that he was also aware of the work being done by historical linguists. It can therefore safely be argued that Darwin's hypothetical evolutionary branching diagram, as an icon, did not introduce any new type of imagery. What changed with the publication of Origin was the way in which the tree iconography, and the natural relations between the elements depicted on the tree, would be explained. Haeckel for example, made exactly this point, when he entitled his 1866 book "Generelle Morphologie der Organismen: allgemeine Grundzüge der organischen Formen-Wissenschaft, mechanisch begründet durch die von Charles Darwin reformierte Descendenz-Theorie" i.e., General Morphology of Organisms: General Outline of the Theory of Organic Form, Mechanically Justified by Charles Darwins Reformed Theory of Descent. This title makes it clear to the reader that there already existed (geneaological) descent theories, but a new mechanism was introduced to explain this common descent, which also explained the morphology of animals. Darwin argued that the affinities that are shared by species were inherited, and these traits were subject to natural selection, a mechanism that resulted in the transmutation of species.

In the Generelle Morphology der Organismen, Haeckel would draw the first organismal tree (Fig. 18). And together with Schleicher, Haeckel would be responsible for the artistic creations and popular spread of "Stammbaum" iconography to depict evolutionary descent with modification by means of natural selection. Haeckel would also draw comparisons between organismal and linguistic trees, and in his 1874 work on human evolution (Antropogenie), he included both a genealogical tree of humans and one of Schleichers' Indo-European family trees (Fig. 19). In all 


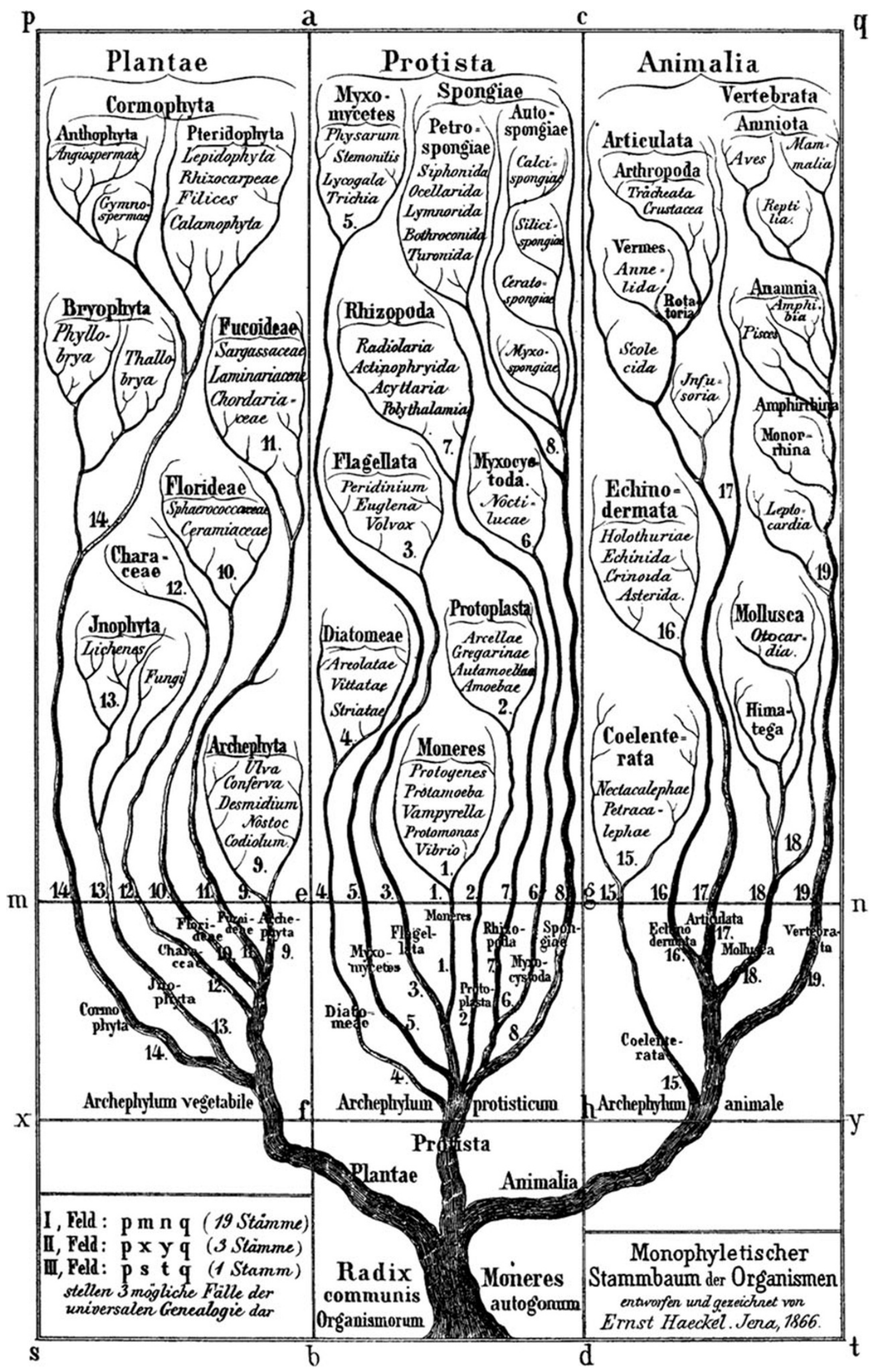


images, the historical roots of the elements of tree iconography are clearly visible, especially by the use of brackets. The historical connectedness with Porphyrian trees was probably unknown. Nonetheless, keys remain a common way to depict classifications in all of Haeckel's works.

\section{Conclusions}

In order to trace the intellectual and cultural roots of the current evolutionary trees, we had to take a fascinating journey through time. Tree diagrams as we know them are first and foremost an outgrowth of philosophical attempts to find the true order and ontological structure of the world, an idea that can itself be traced back to most written cultures.
Non-evolutionary tree diagrams originated first in the form of Arbor Porphyriana that served as a visual aid for the depiction of logical relationships between substances. Associated with these logical trees was the idea of a great chain of being that was first formulated by Aristotle: all of the non-living as well as living world could be hierarchically classified from inanimate to animate matter. These ideas would be synthesized with the preachings of the three Abrahamic religions (Judaism, Christianity and Islam).

Both scales of nature (scala naturae) and chains of being would become a common element by which the divine order in the world was depicted. With the increase in knowledge, an increase that alchemists especially would be responsible for, these scales would incorporate an everincreasing number of natural elements.
Zehnte Tabelle.

Stammbaum der indogermanischen Sprachen.

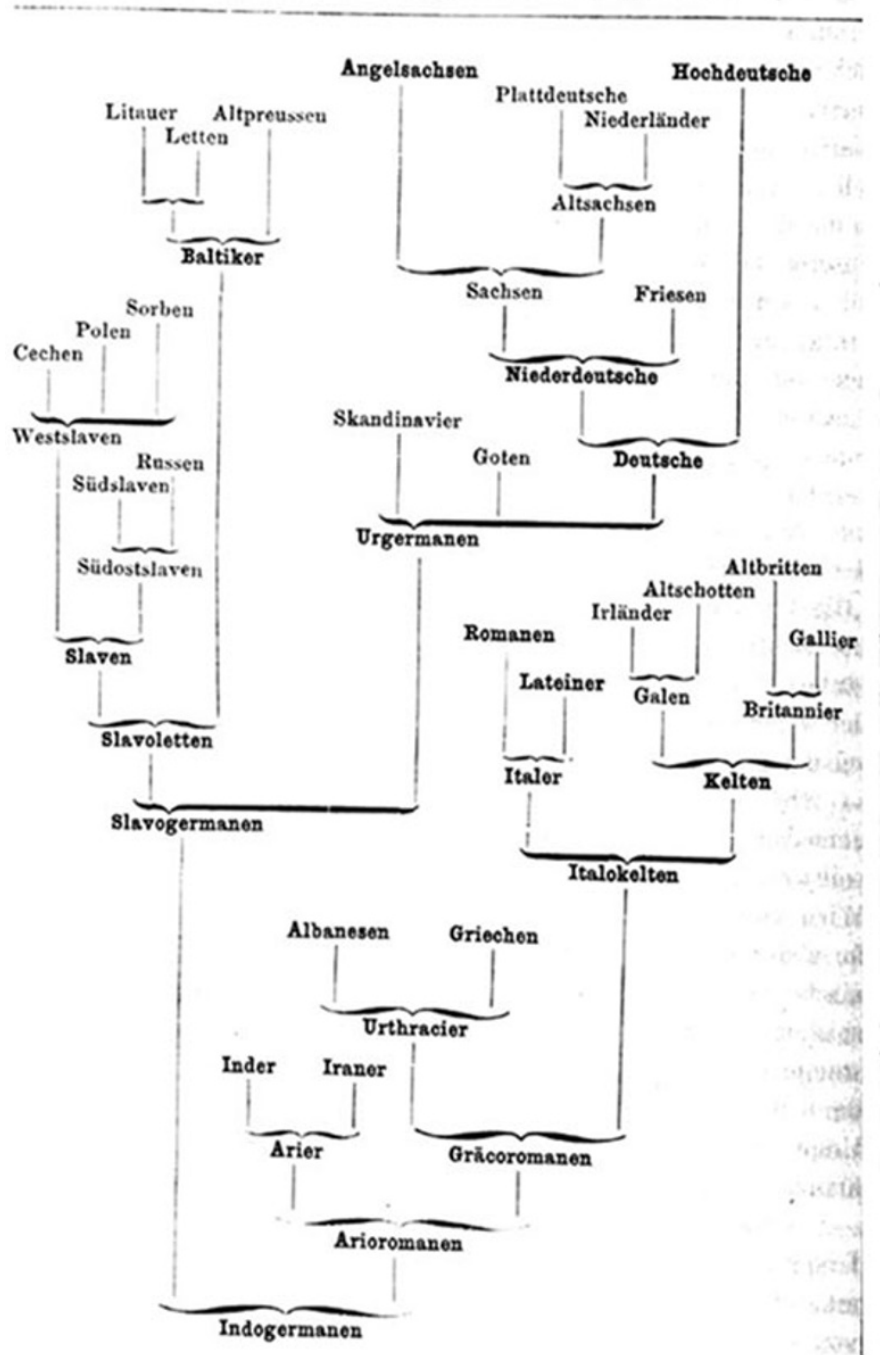

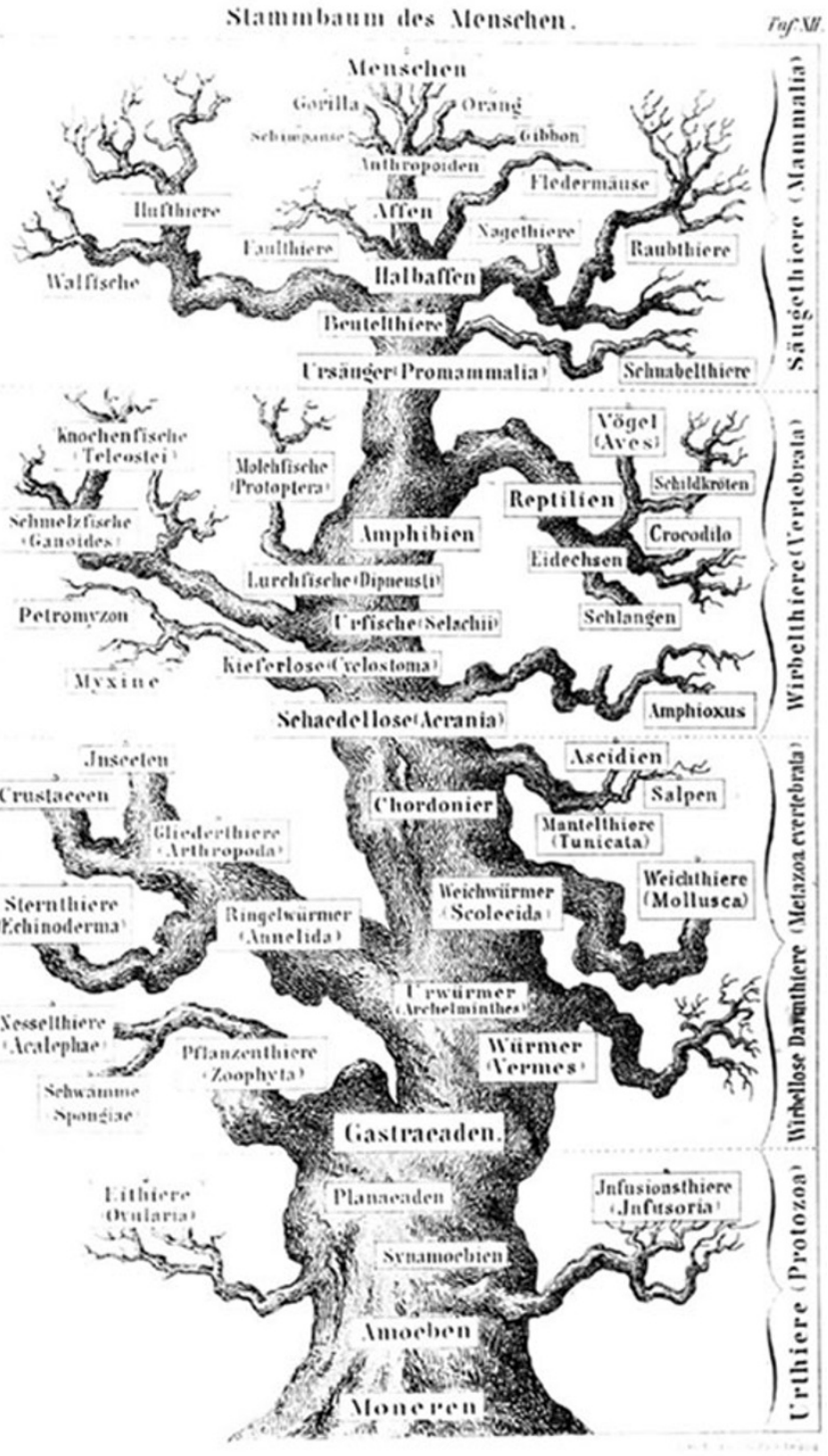

Fig. 19 Left, Haeckel's representation of Schleicher's tree of the Indo-Germanic language family. Right, his own tree depicting the long evolutionary history of life that precedes the evolution of man (Haeckel 1874: 360 and 497) 
Especially religious thinking would furthermore introduce genealogical thinking: the kinship of both divine and natural beings would be reconstructed and also these pedigrees would be depicted in tree iconographies.

From the late eighteenth century onward, the scales of nature would blend with pedigree thinking and lie at the formation of tree diagrams that also depict the element of time. From the nineteenth century onward, the elements on a pedigree would be combined based upon theorizing on affinities rather than ontological essences.

The idea of affinities and the recognition that affinities were the result of common historical descent would introduce evolutionary thought, first in linguistics, and later in the rest of the natural sciences of the nineteenth century.

After natural selection was introduced as the principle mechanism that explained the natural and historical affinity between species, tree diagrams became the most common way to illustrate theories of evolution.

The ways in which ancient tree diagrams have found their way into evolutionary thought have therefore, knowingly or unknowingly, been strongly biased toward these philosophical and religious ideas. It therefore simply cannot be argued, as has been done by Dennett et al. (2009), that debunking the current tree of life images feeds into creationist thought.

Acknowledgments This article is the outgrowth of a presentation given at the April 2009 Lisbon colloquium "Illustration in Darwin: The tree as the image of life's evolution," which was held at the Science Pavilion of Ciência Viva and organized by the Centre for Philosophy of Science of the University of Lisbon, Portugal. A PowerPoint of that presentation that includes more tree of life images can be found at http://www.darwin2009.pt/img/upload/nathalie.pdf. I would like to sincerely thank Niles Eldredge for kindly inviting me to contribute this paper to Evolution: Education and Outreach, and for commenting on a previous draft. I kindly acknowledge one of my former students, Ricardo Reis dos Santos, for hunting down tree diagrams with me. And warm thanks also go out to Mary Bouquet, Olga Pombo, Jonathan Barnes, Giulio Barsanti, and Eyólfur Kjalar Emilsson for guiding me through ancient times.

\section{References}

Alter SG. Darwinism and the linguistic image: language, race and natural theology in the nineteenth century. Baltimore: John Hopkins University Press; 1999.

Anonymous. The Bible. Authorized King James version with Apocrypha. Oxford: Oxford University Press; 1997.

Archibald JD. Edward Hitchcock's pre-Darwinian (1840) "Tree of life". J Hist Philos. 2009;42(3):561-92. doi:10.1007/s10739-008-9163-y.

Atkinson QD, Gray RD. Curious parallels and curious connections: phylogenetic thinking in biology and historical linguistics. Syst Biol. 2005;54:513-26. doi:10.1080/10635150590950317.

Augier A. Essai d'une nouvelle classification des végétaux. Lyon: Bruyset Aine; 1801

Barnes J. The complete works of Aristotle. Princeton: Princeton University Press; 1984.
Barsanti G. La scala, la mappa, l'arbero: Immagini e classificazioni della natura fra Sei e Ottocento. Firenze (Italy): Sansoni; 1992.

Barsanti G. Schémas biologiques de la descendance (XVIIIe-XIXe siècles). In: Gayon J, Wunenburger JJ, editors. Le paradigme de la filiation. Paris: Éditions L'Harmattan; 1995. p. 33-59.

Bouquet M. Family trees and their affinities: the visual imperative of the genealogical diagram. J Roy Anthropol Inst. 1996;2(1): 43-66.

Bowler PJ. Bonnet and Buffon: theories of generation and the problem of species. J Hist Biol. 1973;6(2):259-81.

Bronn HG. Untersuchungen über die Entwickelungs- Gesetze der organischen Welt während der Bildungs-Zeit unserer ErdOberfläche. Stuttgart: E. Schweizerbart'sche Verlagshandlung und Druckerei; 1858.

Burrow JW. Editor's introduction. In: Burrow JW, editor. Charles Darwin: The origin of species. Penguin: Harmondsworth; 1972. p. 11-48.

Čelakovský F. Ctení o srovnavací mluvnici slovanské na Universitě pražskě. Prague: F. Řivnáče; 1853.

Condillac EB de. Essai sur l'Origine des Connoissances Humaines: Ouvrage où l'on Réduit à un Seul Principe Tout ce qui concerne l'Entendement Humain. Institut National de la Langue Française, CNRS. 1746. http://gallica.bnf.fr/ark:/12148/bpt6k87990k.item

Coseriu E. Geschichte der Sprachphilosophie von der Anfängen bis Rousseau: Neu bearbeitet und erweitert von Jörn Albrecht: A. Tübingen/Basel: Frankce Verlag; 2003.

Darwin C. On the origin of species. London: John Murray; 1859.

Darwin C. The descent of man. London: John Murray; 1871.

De Libera A. La Philosophie Médiévale. Paris: Presses Universitaires de France; 1995.

Dennett D, Coyne J, Dawkins R, Myers P. Darwin was right. New Sci. 2009;201(2696):25.

Deverreux D, Pellegrin P, editors. Biologie, Logique et Métaphysique chez Aristote. Paris: Éditions du Centre National de la Recherche Scientifique; 1990.

Ecco U. The search for the perfect language. Oxford: Blackwell; 1995.

Emilsson EK. Porphyry. In: Zalta EN, editor. The Stanford Encyclopedia of Philosophy; 2005. http://plato.stanford.edu/archives/ sum2011/entries/porphyry.

Fludd R. Utriusque cosmic maioris scilicet et minris metaphysica, physica atque technical historia. (2 vol.) Oppenheim: Johann Theodore de Bry; 1617-1621.

Fowler HN. Plato in twelve volumes, translated by Harold N. Fowler. Cambridge: Harvard University Press; 1921.

Frank RM. The language-organism-species analogy: a complex adaptive systems approach to shifting perspective on 'language'. In: Frank RM, Dirven R, Ziemke T, Bernárdez E, editors. Body, Language and Mind. Vol. 2. Sociocultural Situatedness. 2nd ed. Berlin: Mouton de Gruyter; 2008. p. 215-62.

Frank RM, Gontier NL. On constructing a research model for historical cognitive linguistics (HCL): some theoretical considerations. In: Winters ME, Tissari $\mathrm{H}$, Allan $\mathrm{K}$, editors. historical cognitive linguistics. Berlin: De Gruyter Mouton; 2010. p. 31-69.

Gontier N. The origin of the social approach in language and cognitive research exemplified by studies into the origin of language. In: Pishwa $\mathrm{H}$, editor. Language and social cognition: expressions of the social mind. Berlin: Mouton de Gruyter; 2008. p. $25-46$.

Griffioen D. Zeventiende eeuwse opvattingen over de 'Harmonie der sferen': Robert Fludd, Johannes Kepler, Athanasius Kircher. Unpublished Master's dissertation. Utrecht: University of Utrecht. 1996. http://www.17thcenturyideas.com/muziekw/scr/ titelpag.html

Haeckel E. Generelle Morphologie der Organismen. I \& IIth ed. Berlin: Georg Reimer; 1866. 
Haeckel E. Athropogenie oder Etnwickelungsgeschichte des Menschen. Leipzig: Engelmann; 1874.

Hillar M. The Logos and its function in the writings of Philo of Alexandria: Greek interpretation of the Hebrew myth and foundations of Christianity. Part I. J Radic Reform: Testimony Biblical Unit. 1998;7(3):22-37.

Hobbes T. Leviathan. London: Penguin; 1968 (Original edition 1651).

Hsüan K, Crowley A. The Tao-teh-Ching. A new translation with commentary by Ko Hsüan. The Equinox vol. 3 (8). Memphis: Samual Weiser, Inc.; 1995 (1923).

Hull DL. Species, languages and the comparative method. Selection. 2002;3(1):17-28.

Kapadia SA. The teachings of Zoroaster and the philosophy of the Parsi religion. London: Murray; 1905.

Kaplan A. The Bahir (translation). Newburyport: Weiser Books; 1989.

Kircher A. Edipus Ægypticus. Rome; 1652.

Lamarck A. Philosophié Zoologique. Paris: Dentu; 1809.

Lichtheim M. Ancient Egyptian literature, vol. 3: the Late period. Berkeley: University of California Press; 1976.

Linnaeus C. Systema Naturae. Leyden: Theodorum Haak; 1735.

Llull R. De ascendu et descensu intellectus. 1304. In: De Proaza A, editor. Raymundi Lully Doctoris illuminati De nova logica, De correlatiuis nec non, et De ascendu et descensu intellectus. València: Jorge Costilla; 1512.

Llull R. De nova logica. 1303. In: De Proaza A., editor. Raymundi Lully Doctoris illuminati De nova logica, De correlatiuis nec non, et De ascendu et descensu intellectus. València: Jorge Costilla; 1512.

Lovejoy AO. The great chain of being: a study of the history of an idea. Cambridge: Harvard University Press; 1936.

Maher J. Introduction. In: Koerner EFK, editor. Linguistics and evolutionary theory. Amsterdam: John Benjamins Publishing Co.; 1983. p. xvii-xxxii.

McKirahan R. Presocratic philosophy. In: Shields C, editor. The Blackwell guide to ancient philosophy. Oxford: Blackwell; 2003. p. 5-25.

Morpurgo-Davies A. History of linguistics. Vol. IV: nineteenth-century linguistics. London: Longman; 1992.

Müller FM. The Upanishads: sacred books of the East. Oxford: Oxford University Press; 1900.

O'Hara RJ. Trees of history in systematics and philology. Mem Soc Ital Sci Nat. 1996;27:81-8.

Pombo O. Leibniz and the problem of a universal language. Münster: Nodus Publikationen; 1987.
Pombo O. Unidade da ciência: Programas, figures e metáforas. Charneca de Caparica: Edições Duarte Reis; 2006.

Priestly TM.S. Schleicher, Čelakovský, and the family-tree diagram: a puzzle in the history of linguistics. Hist Ling 1975; 299-333.

Ragan MA. Trees and networks before and after Darwin. Biology Direct. 2009;4:43. doi:10.1186/1745-6150-4-43.

Riccius P. De Portae Lucis R. Josephi Gecatilia. Augsburg; 1516.

Richards RJ. The linguistic creation of man: Charles Darwin, August Schleicher, Ernst Haeckel, and the missing link in the nineteenthcentury evolutionary theory. In: Dörries M, editor. Experimenting in tongues: Studies in science and language. Stanford: Standford University Press; 2002. p. 21-48.

Rieppel $\mathrm{O}$. The series, the network, and the tree: changing metaphors of order in nature. Biol Philos. 2010;25:475-96.

Rousseau JJ. Essai sur l'Origine des Langues: Ou il le parle de la Mélodie et de l'Imitation Musicale. [Edition, Introduction et Notes par Charles Porset.]. Bordeaux: Ducros; 1971. original edition 1781.

Schleicher A. Die ersten Spaltungen des indogermanischen Urvolkes. Allgemeine Montschrifr für Wissenschapft und Literatur. 1853;1853:786-7.

Schleicher A. Compendium der vergleichenden Grammatik der indogermanischen Sprache. Weimar: Böhlan; 1861.

Schleicher A. Die Darwinische Theorie und die Sprachwissenschaft. Weimar: Böhlan; 1863.

Scholem GG. Zohar: The Book of Splendor: Basic Readings from the Kabbalah. Schocken: 1995.

Schwartz JH. Sudden origins: fossils, genes, and the emergence of species. New York: John Wiley and sons incorporate; 1999.

Silver BL. The ascent of science. Oxford: Oxford University Press; 2000.

Stevens PF. Augstin Augier's 'arbre botanique' (1801), a remarkable early botanical representation of the natural system. Taxon. 1983;32(2):203-11.

Van Wyhe J. The descent of words: evolutionary thinking 1780-1880. Endavour. 2005;29(3):94-19. doi:10.1016/j.endavour.2005.07.002.

Weigel S. Genealogy: on the iconography and rhetorics of an epistemological topos. 2003. www.educ.fc.ul.pt/hyper/resources/ sweigel.

Wilkins J. Defining species: a sourcebook from antiquity to today. New York: Peter Lang; 2009.

Williams JAH. The earliest dated Tree of Jesse image: thematically reconsidered. Athanor. 2000;XVIII:17-23. 